\title{
Long-term changes in drought indices in eastern and central Europe
}

\author{
Jaak Jaagus $^{1}$ (i) | Anto Aasa ${ }^{1}$ | Svetlana Aniskevich ${ }^{2}$ | Boris Boincean $^{3}$ | \\ Roxana Bojariu $^{4}$ | Agrita Briede ${ }^{5}$ | Irina Danilovich ${ }^{6}$ | \\ Fernando Domínguez Castro $^{7,8}$ | Alexandru Dumitrescu ${ }^{4}$ | | Martin Labuda ${ }^{9}$ | \\ Lívia Labudová $^{10}$ | Krista Lõhmus ${ }^{1}$ | Viktar Melnik ${ }^{6}$ | Kiira Mõisja ${ }^{1}$ | \\ Rita Pongracz $^{11}$ | Vera Potopováa ${ }^{12}$ ( ) | Ladislava Řezníčková ${ }^{13,14}$ | \\ Egidijus Rimkus $^{15}$ | Inna Semenova ${ }^{16}$ | Edvinas Stonevičius $^{15}$ |

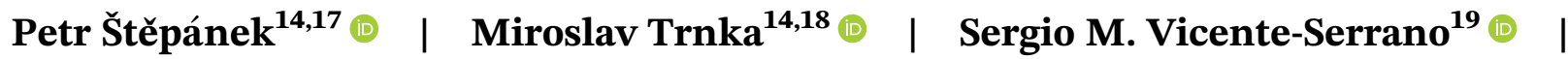 \\ Joanna Wibig $^{20}$ (i) | Pavel Zahradníček ${ }^{14,17}$ \\ ${ }^{1}$ Department of Geography, Institute of Ecology and Earth Sciences, University of Tartu, Tartu, Estonia \\ ${ }^{2}$ Climate and Methodological Division, Latvian Environment, Geology and Meteorology Centre, Riga, Latvia \\ ${ }^{3}$ Department of Sustainable Farming Systems, Selectia Research Institute of Field Crops, Balti, Republic of Moldova \\ ${ }^{4}$ National Meteorological Administration, Bucharest, Romania \\ ${ }^{5}$ Department of Geography, Faculty of Geography and Earth Sciences, University of Latvia, Riga, Latvia \\ ${ }^{6}$ Centre for Climate Research, Institute for Nature Management National Academy of Sciences, Minsk, Belarus \\ ${ }^{7}$ Aragonese Agency for Research and Development (ARAID), Zaragoza, Spain \\ ${ }^{8}$ Department of Geography, University of Zaragoza, Zaragoza, Spain \\ ${ }^{9}$ Department of Environmental Ecology and Landscape Management, Faculty of Natural Sciences, Comenius University in Bratislava, Bratislava, \\ Slovakia \\ ${ }^{10}$ Department of Climatological Service, Slovak Hydrometeorological Institute, Bratislava, Slovakia \\ ${ }^{11}$ Department of Meteorology, Eötvös Loránd University, Budapest, Hungary \\ ${ }^{12}$ Department of Agroecology and Crop Production, Czech University of Life Sciences, Prague, Czech Republic \\ ${ }^{13}$ Department of Geography, Masaryk University, Brno, Czech Republic \\ ${ }^{14}$ Domain of Climate Analysis and Modeling, Global Change Research Institute of the Czech Academy of Sciences, Brno, Czech Republic \\ ${ }^{15}$ Institute of Geosciences, Vilnius University, Vilnius, Lithuania \\ ${ }^{16}$ Department of Military Training, Odessa State Environmental University, Odessa, Ukraine \\ ${ }^{17}$ Brno Regional Office, Czech Hydrometeorological Institute, Brno, Czech Republic \\ ${ }^{18}$ Department of Agrosystems and Bioclimatology, Mendel University in Brno, Brno, Czech Republic \\ ${ }^{19}$ Instituto Pirenaico de Ecología, Spanish National Research Council (IPE-CSIC), Zaragoza, Spain \\ ${ }^{20}$ Department of Meteorology and Climatology, University of Łódż, Łódż, Poland
}

\section{Correspondence}

Jaak Jaagus, Department of Geography, Institute of Ecology and Earth Sciences, University of Tartu, Vanemuise 46, 51003 Tartu, Estonia.

Email: jaak.jaagus@ut.ee

Funding information

Ministry of Education and Research of

\section{Abstract}

This study analyses long-term changes in drought indices (Standardised Precipitation Index-SPI, Standardised Precipitation-Evapotranspiration Index-SPEI) at 1 and 3 months scales at 182 stations in 11 central and eastern European countries during 1949-2018. For comparative purposes, the necessary atmospheric evaporative demand (AED) to obtain SPEI was calculated 
Estonia, Grant/Award Number: PRG-352; EU JPI WATER using two methods, Hargreaves-Samani (SPEIH) and Penman-Monteith (SPEIP). The results show some relevant changes and tendencies in the drought indices. Statistically significant increase in SPI and SPEI during the cold season (November-March), reflecting precipitation increase, was found in the northern part of the study region, in Estonia, Latvia, Lithuania, northern Belarus and northern Poland. In the rest of study domain, a weak and mostly insignificant decrease prevailed in winter. Summer season (June-August) is characterized by changes in the opposite sign. An increase was observed in the north, while a clear decrease in SPEI, reflecting a drying trend, was typical for the southern regions: the Czech Republic, Slovakia, Hungary, Romania, Moldova and southern Poland. A general drying tendency revealed also in April, which was statistically significant over a wide area in the Czech Republic and Poland. Increasing trends in SPI and SPEI for September and October were detected in Romania, Moldova and Hungary. The use of SPEI instead of SPI generally enhances drying trends.

\section{KEYW O R D S}

atmospheric evaporative demand, central and eastern Europe, drought, SPEI, SPI, trend analysis

\section{1 | INTRODUCTION}

There is no clear global trend in drought severity, although some few regions have still shown significant trends over the last decades (Spinoni et al., 2019). Considering precipitation dynamics, recent global studies have not suggested relevant changes in drought severity (Orlowsky and Seneviratne, 2013; Spinoni et al., 2017, 2019). Nevertheless, thermodynamic issues could play a relevant role as a consequence of global warming processes. The increased air temperature and decreased relative humidity (Willett et al., 2014; Vicente-Serrano et al., 2018) have increased the atmospheric vapour pressure deficit (VPD) (Yuan et al., 2019) and the atmospheric evaporative demand (AED) (Vicente-Serrano et al., 2020). The last characteristic could be increasing the severity of drought events (Vicente-Serrano et al., 2014; García-Herrera et al., 2019; Wu et al., 2019), particularly in water limited regions and during the periods of precipitation deficit (Vicente-Serrano et al., 2020).

Although the available global studies provide a general overview of the recent drought behaviour, these studies are affected by important, mostly dataset-related uncertainties. Global gridded and reanalysis datasets are affected by inconsistencies and possible spatial and temporal inhomogeneities (Stillman et al., 2016). In addition, they are much limited by the availability of meteorological series in the main data repositories, which usually are incomplete and do not take into account a large number of series collected by the different national meteorological services. Moreover, drought has a high spatial variability because it depends very much on the influence of dynamic mechanisms, which may differ notably between neighbouring regions (García-Herrera et al., 2007; Kingston et al., 2015; Vicente-Serrano et al., 2016). This stresses the need for developing a regional analysis based on high-quality datasets to be able to improve the robustness of the knowledge of recent drought changes.

We have focused our study on eastern and central Europe. The area forms a transient meridional belt between the region of the maritime climate in western Europe and the region of continental climate in Russia. High variability of weather conditions makes eastern and central Europe very vulnerable to climate change (IPCC, 2013). Our study region covers 11 countries-Estonia, Latvia, Lithuania, Belarus, Poland, Ukraine, Czech Republic, Slovakia, Hungary, Moldova and Romania. This area covers up to 1.8 million square kilometres and its population is approximately 150 million. Drought is one of the main meteorological risks in the region affecting different economic sectors and environmental systems including agriculture (Szwed et al., 2010; Moore and Lobell, 2015; Potopová et al., 2020), forestry (Leuzinger et al., 2005; Bachmair et al., 2018; Rita et al., 2019) and water supply (Wilhite, 2005; Van Loon et al., 2015; Danilovich et al., 2019).

The analysis of trends in drought indices in this region is highly relevant because future climate projections indicate an increase in the severity of droughts in the coming decades (IPCC, 2013; Anders et al., 2014; Spinoni et al., 2018, 2020; Hari et al., 2020). Two main reasons allow us to expect an increase of drought in the 
current climate change scenario over central and eastern Europe. The first reason is the fact that higher temperature increases VPD and AED, leading to stronger transpiration by vegetation and evaporation from water bodies in the cases that water reserves exist, contributing to the development of stronger hydrological droughts (VicenteSerrano et al., 2020), but also to stronger vegetation stress during periods of soil moisture deficit (Allen et al., 2015). The second reason is related to the snow cover regime. With mild winters, a permanent deep snow cover does not form. Snow cover appears and disappears many times during a winter. In this case, snow melting in spring and highwater level in rivers becomes much weaker and they are shifted to the earlier time (Jaagus et al., 2017). Consequently, the soil water content will be much lower in the beginning of the growing season, favouring the formation of drought conditions much earlier in spring and summer.

In this study, we concentrated on the analysis of meteorological drought, which usually is the origin of other drought types as hydrological, agricultural or environmental drought (Vicente-Serrano et al., 2016; Wilhite and Pulwarty, 2017). Meteorological drought is usually defined on the basis of the degree of dryness (in comparison to some "normal" or average amount) and the duration of the dry period (NDMC, 2021). The analysis of meteorological droughts is usually based on drought indices, which are considered suitable for describing moisture conditions in a region (Heim, 2002; Mukherjee et al., 2018). Some analyses based on drought indices in central and eastern Europe have already been made. For example, Rimkus et al. (2012) suggested a decline in dryness in the major part of the Baltic area based on a drought index (SPI) calculated with precipitation data. Using precipitation and different metrics of the atmospheric evaporative demand, different studies have showed an increase in the severity of drought events in Ukraine and Belarus (Semenova and Sumak, 2017; Stonevičus et al., 2018), central Poland (Somorowska, 2016), the Czech Republic and Slovakia (Trnka et al., 2016; Labudová et al., 2017), and Moldova (Potopová et al., 2016). Nevertheless, no authors have analysed our current study region by using the same comparable drought indices, the same methodology to estimate AED and the same analysis period.

The main objective of this study is to analyse trends in drought indices SPI and SPEI in eastern and central Europe during the 70-year period (1949-2018) by the use of precipitation-based drought indices, but also to determine the possible role of AED in current drought trends. Such analysis is important for better understanding of ongoing changes in drought conditions, which is necessary to improve or promote the implementation of drought management plans in different sectors such as agriculture or water supply. The link between drought and the functioning of these sectors has already been affirmed in several national-level studies (Rimkus et al., 2012; Dumitrescu et al., 2015; Potopová et al., 2016; Somorowska, 2016; Trnka et al., 2016). But there is also a need to look at it on transboundary level. Only then can the most endangered regions be identified. For the generalization of the results, we worked out a classification of the stations and a regionalization of the study area based on similarities of changes in drought indices.

\section{2 | DATA AND METHODS}

We used meteorological data from 182 stations located in 11 eastern and central European countries (Figure 1). Station names and their numbers are listed in the Appendix. We used monthly precipitation and monthly mean maximum and minimum temperature during the period of 70 years (1949-2018). This is the time frame for the continuous data of meteorological measurements made in the study region after the gaps which had occurred during the World War II. In addition, monthly mean air pressure on station level, relative humidity, wind speed and sunshine duration were available at 46 meteorological stations in Estonia, Latvia, Lithuania, Poland, Belarus, Czech Republic and Slovakia, which are marked on Figure 1. Eight Belarus stations, which measured sunshine duration, had some gaps in measurements at the beginning (first 510 years) of the study period, which were restored using the data from the nearest two stations (Pinsk and Mar'ina Gorka). The data for total cloudiness at six Belarus stations were also restored with the help of these two stations. The highest spatial density of the measurement network was in the Czech Republic with 46 stations, and the lowest in Ukraine, Slovakia and Hungary. All the data were obtained from the national weather services except Ukrainian data, which were obtained from the ECA\&D dataset (Klein Tank et al., 2002). In some cases, it was impossible to obtain a full coverage of data. For example, the majority of time series from Moldova start in 1950, and the time series from Romania end in January 2018. We assume that these small gaps in the beginning and in the end of the study period had no effect on the results of the trend analysis.

The data have passed a quality control at the national weather services. Additionally, MetQC data quality control and homogenization of time series have been applied using ProClimDB and AnClim software (www.climahom. eu). Both data quality control and homogenization are based on running and combining several statistical tests. Details are described in Štěpánek et al. $(2011,2013)$ and its recent application in Zahradníček et al. (2014, 2019). Some erroneous data have been found and corrected (tens of values in case of maximum and minimum 

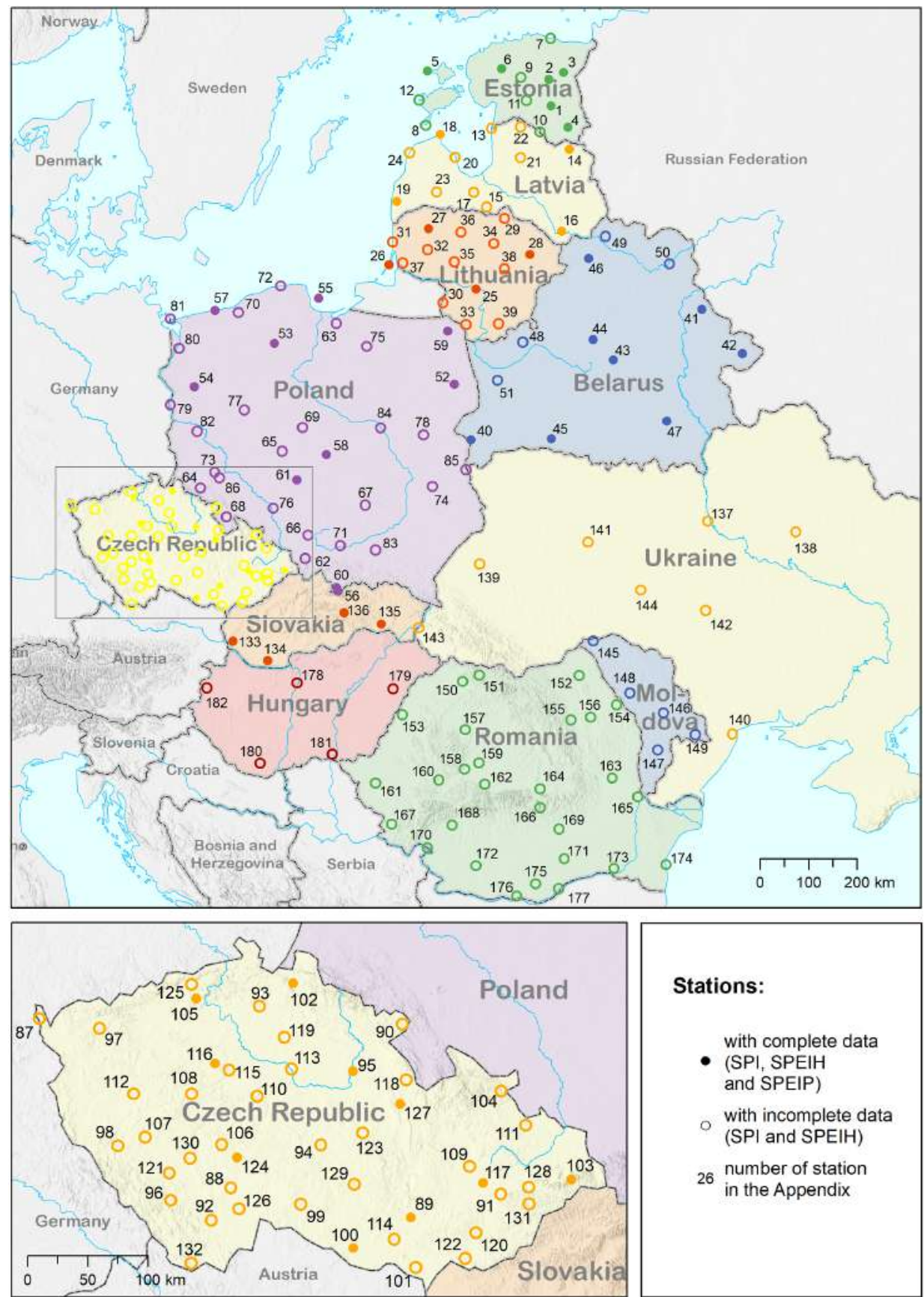

FI G URE 1 Location of the 182 stations used in this study. The list of stations with their numbers is presented in the Appendix [Colour figure can be viewed at wileyonlinelibrary.com] temperature and precipitation, and units of values in case of other meteorological elements). Ten stations have been excluded from further processing due to statistically significant breaks in time series related to relocations of the observation site.

We have used two drought indices: the Standardized Precipitation Index (SPI, McKee et al., 1993) and the Standardized Precipitation Evapotranspiration Index (SPEI; Vicente-Serrano et al., 2010). The first index is based only on precipitation data while the second one is based on the difference between precipitation and AED. The best approach to represent the influence of AED on drought severity is to use a physically based model, that is, the Penman-Monteith approach (Allen et al., 1998), but this method requires several variables to consider-both aerodynamic and radiative components of AED (Allen et al., 1998). The use of empirical models to estimate AED based on air temperature data is suboptimal (VicenteSerrano et al., 2020). Nevertheless, they offer the unique possibility of computing the role of AED on drought severity over large areas, covered by this study, where the data of wind speed, relative humidity and sunshine duration were not available. We used the Hargreaves-Samani method (Hargreaves and Samani, 1982) to estimate AED used to 

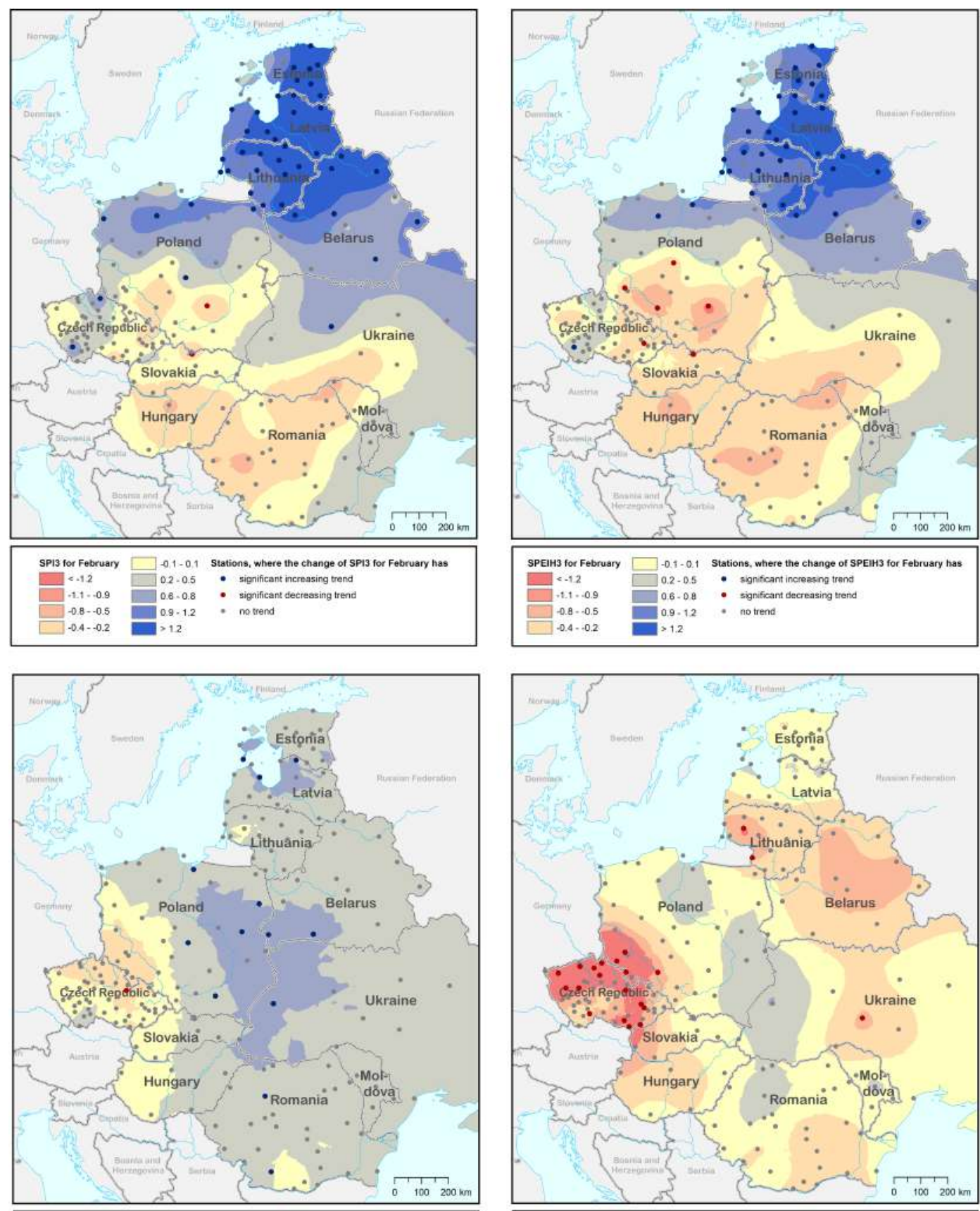

SP13 for May $\square-0.1-0.1$ Stations, where the change of SP13 for May has

$\begin{aligned} & \square \\ & \square-1.2 \\ & 0\end{aligned}-2-0.5 \quad$ - significant increasing trend

$-1,1-0.9 \square 0.6-0.8 \quad-$ significant decroasing trenc

$-0.0 .-0.5 \quad 0.9-1.2$. natrend

$7 \cdot 0.4 \div 0.2 \square>1.2$

F I G U RE 2 Net changes in seasonal SPI3 from 1949 to 2018 for February (a), SPEIH3 for February (b), SPI3 for May (c), SPEIH3 for May (d), SPI3 for August (e), SPEIH3 for August (f), SPI3 for November (g) and SPEIH3 for November (h) [Colour figure can be viewed at wileyonlinelibrary.com]

calculate the SPEI (henceforth SPEIH) as it is recommended by the Food and Agricultural Organization (FAO) (Allen et al., 1998) under conditions of data scarcity. This method is based on the data of maximum and minimum temperature and its results were compared with the estimations of the
Penman-Monteith method (henceforth SPEIP) at the stations where the necessary data were available.

First, we analysed changes in seasonal indices, that is, in SPI3, SPEIH3 and SPEIP3 for February (winter), May (spring), August (summer) and November (autumn). For 

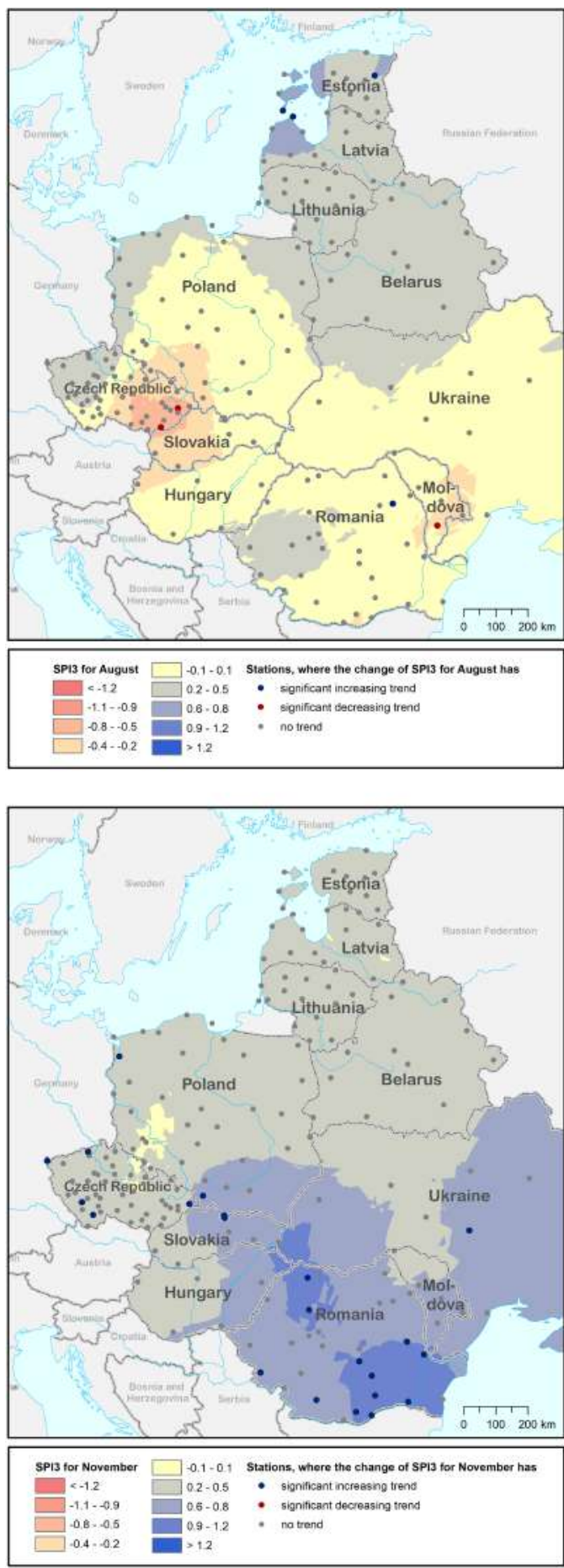

F I G URE 2 (Continued)

example, the SPI3 for May presents here an accumulation of SPI over the previous three months-March, April and May. We also analysed the monthly time series (SPI1, SPEIH1 and SPEIP1). Trend analysis was carried out using the Mann-Kendall test (Mann, 1945; Kendall, 1975). It is a nonparametric method that does not require a normal distribution of the initial time series. The slope was calculated using the Sen's method (Sen, 1968). In the analysis of results, we
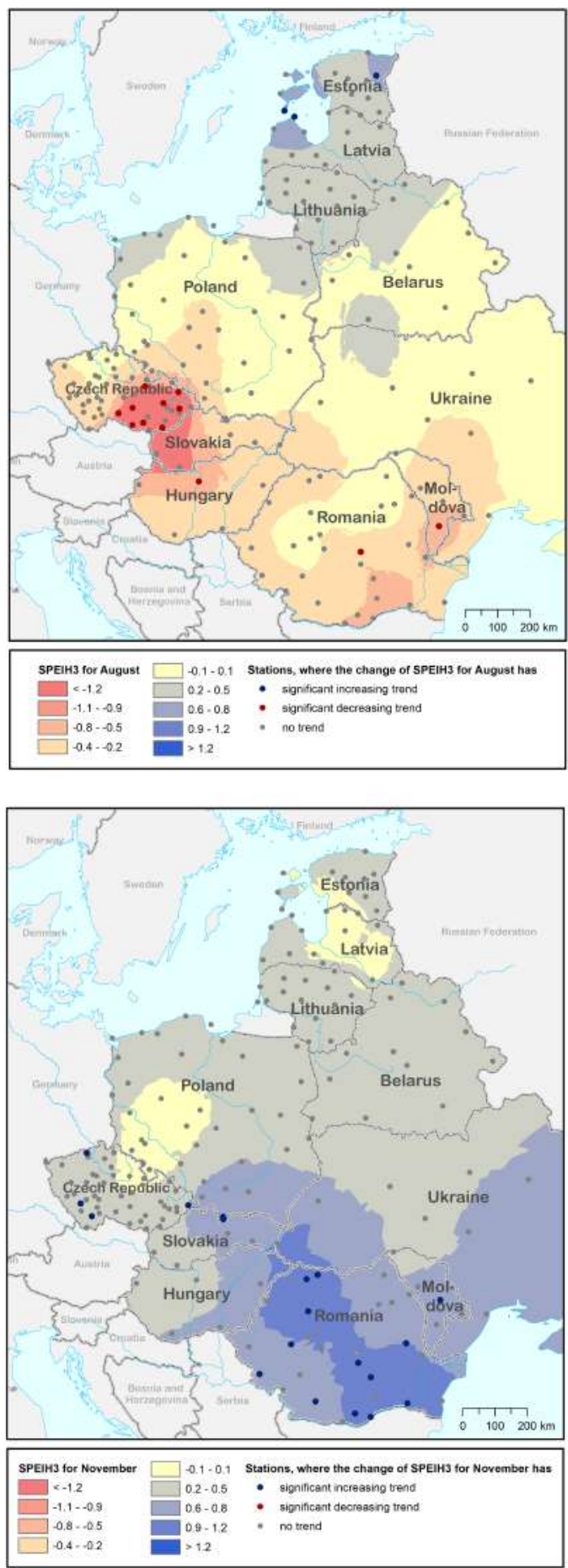

used the total change by trend or the net change as the main characteristic of change. It was calculated by multiplying the slope with the number of years that was 70 in this study. As the SPI and SPEI data are standardized and follow the normal distribution (mean equal to zero and standard deviation equal to one), they are expressed in $z$-values. Net changes have the same units. Changes are considered statistically significant on the $p<.05$ level. The main results of the Mann- 

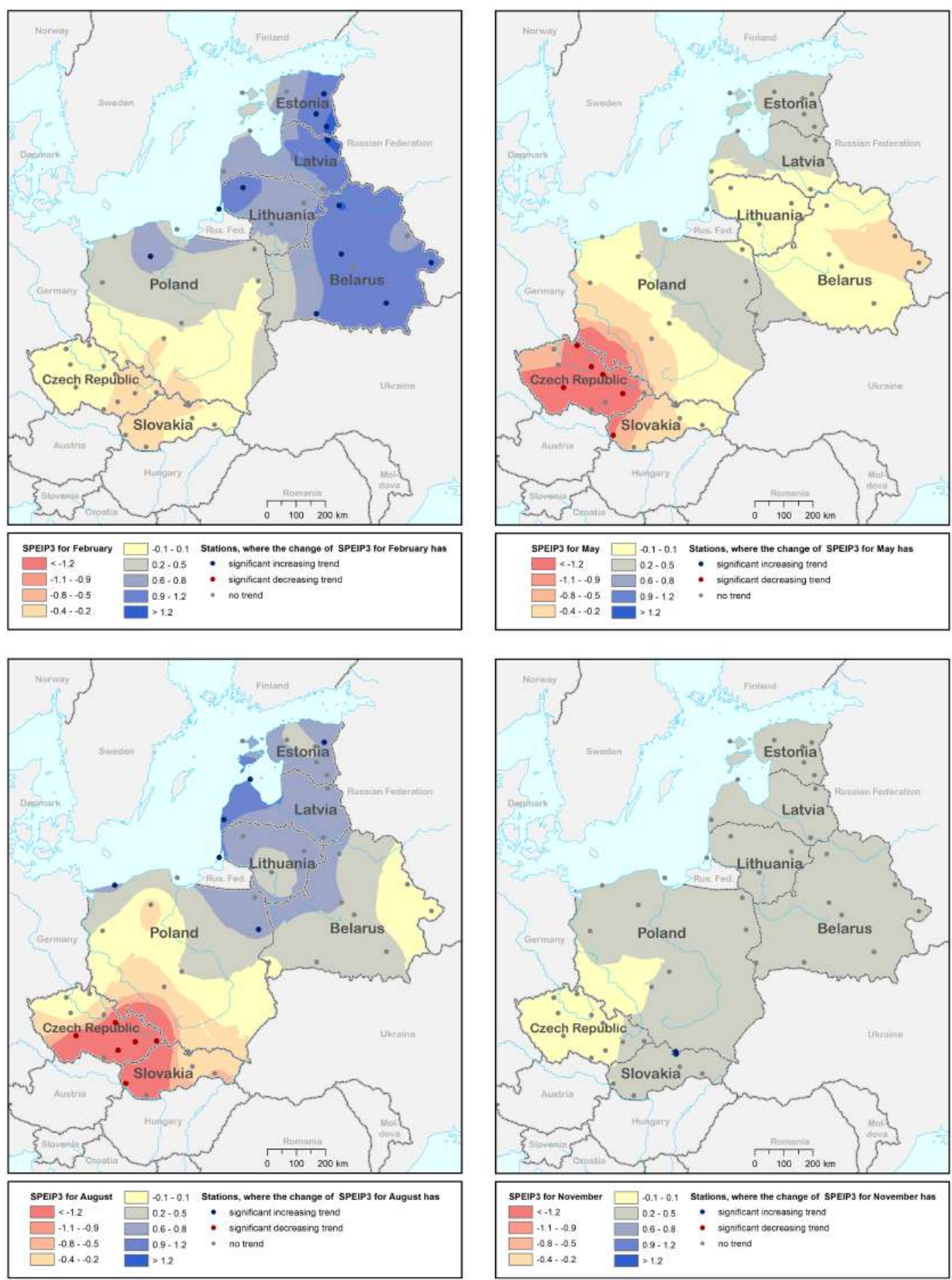

F I G U RE 3 Net changes in seasonal SPEIP3 from 1949 to 2018 for February (a), May (b), August (c) and November (d) [Colour figure can be viewed at wileyonlinelibrary.com]

Kendall test of the drought indices are presented on maps in the form of net changes. They were compiled using the spatial interpolation (kriging). Stations with significant changes on $p<.05$ level are marked.

We used the rotated principal component analysis (RPCA) to group stations according to similarities in trends. We used monthly net changes of SPI1 and
SPEIH1 at the 182 stations for RPCA. The S-mode RPCA (Richman, 1986) was applied where the stations served as the variables, and monthly values of the net changes were the cases in the initial data matrix. Rotation of the main components was accomplished using the varimax raw technique. The number of components for rotation was selected according to the Kaiser criterion (eigenvalue $\geq 1$ ). 

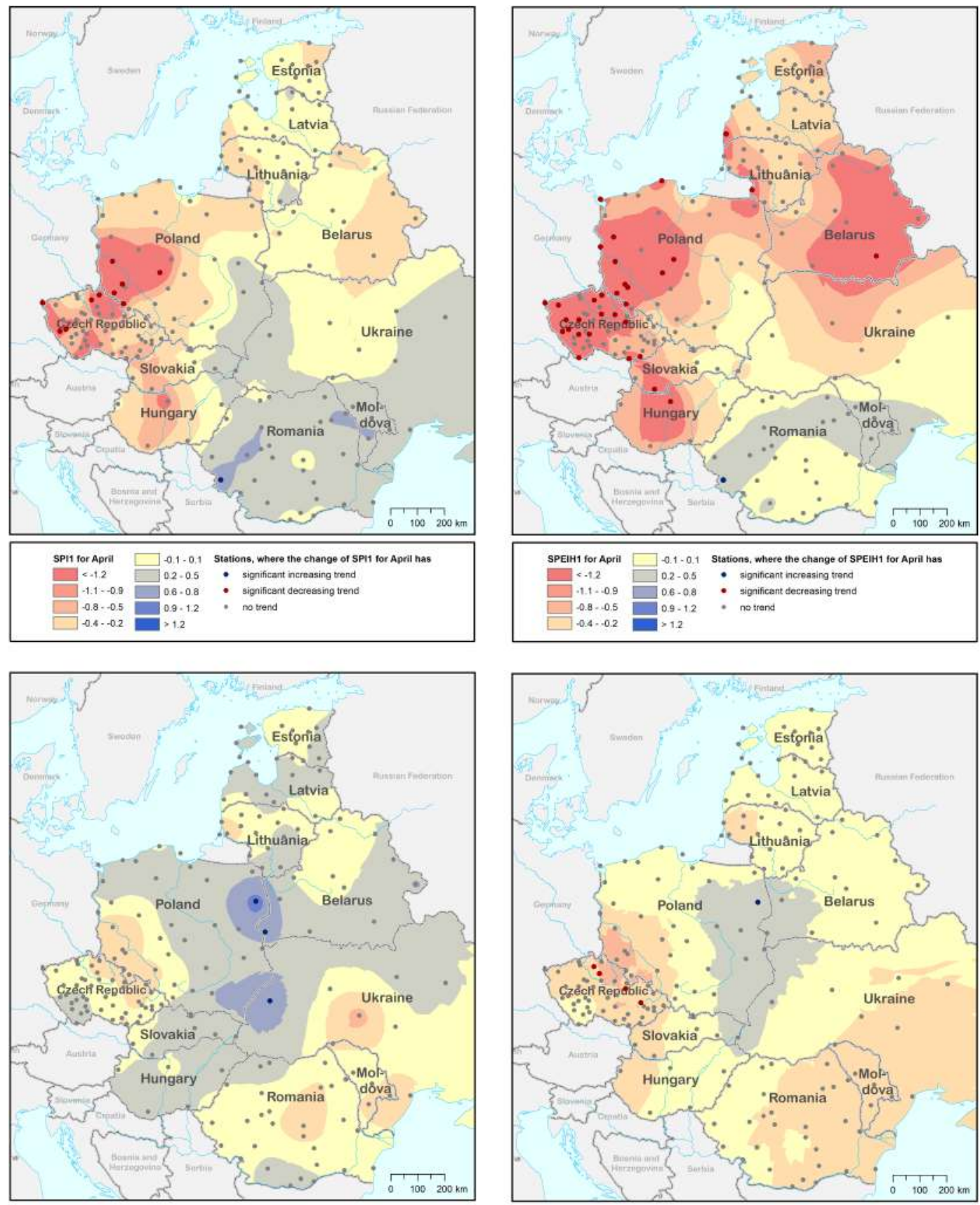

SP11 for May $\square-0.1-0.1$ Stations, whore the change of SPI1 for May has

$\square<-1.2 \square-0.2-0.5 \quad-$ signiticant increasing trend

$-1.1-0.9-0.5-0.8$ - signiticant decreasing trend

- $0.8-0.5$

$-0.4-0.2 \square>1.2$

F I G U R E 4 Net changes in monthly SPI1 from 1949 to 2018 in April (a), SPEIH1 in April (b), SPI1 in May (c), SPEIH1 in May (d), SPI1 in June (e), SPEIH1 in June (f), SPI1 in July (g), SPEIH1 in July (h), SPI1 in August (i), SPEIH1 in August (j), SPI1 in September (k) and SPEIH1 in September (1) [Colour figure can be viewed at wileyonlinelibrary.com]

Accordingly, we found that twelve components had eigenvalues higher than 1. Each station was related to one component, which had the highest loading, that is, the highest correlation between the component and the net changes of monthly drought indices at that station. The loading should be significantly different from zero that is $\geq 0.56$ for 24 cases. If all loadings for a station were below this criterion then the station was not classified. Groups or classes of stations were defined if they consisted of at least three stations. 

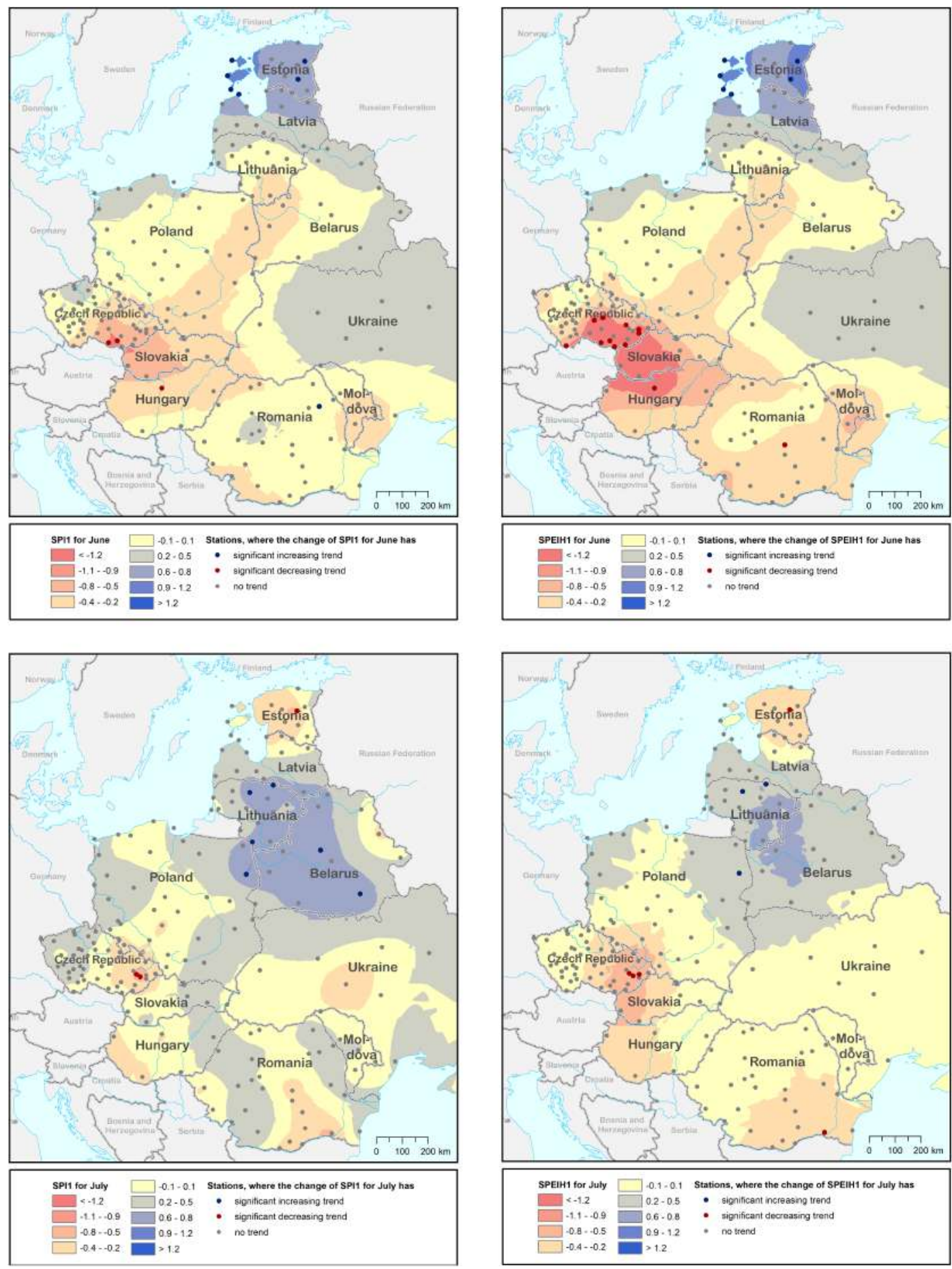

FI G URE 4 (Continued)

\section{3 | RESULTS}

\section{1 | Trends in seasonal drought indices}

Net changes in seasonal drought indices are provided on Figures 2 and 3. Comparing the patterns of changes in winter, that is, for SPI3 (Figure 2a), SPEIH3 (Figure 2b) and SPEIP3 (Figure 3a) for February, we can see that they are very similar. A strong and statistically significant increase manifested in the northern part of the study region, in Estonia, Latvia, Lithuania, Belarus and northern Poland. These changes reflect an increase in winter precipitation. In the southern part of the region-in southern Poland, eastern part of the Czech Republic, Slovakia, Hungary and Romania, a weak and statistically insignificant tendency towards the drying is prevailing. 

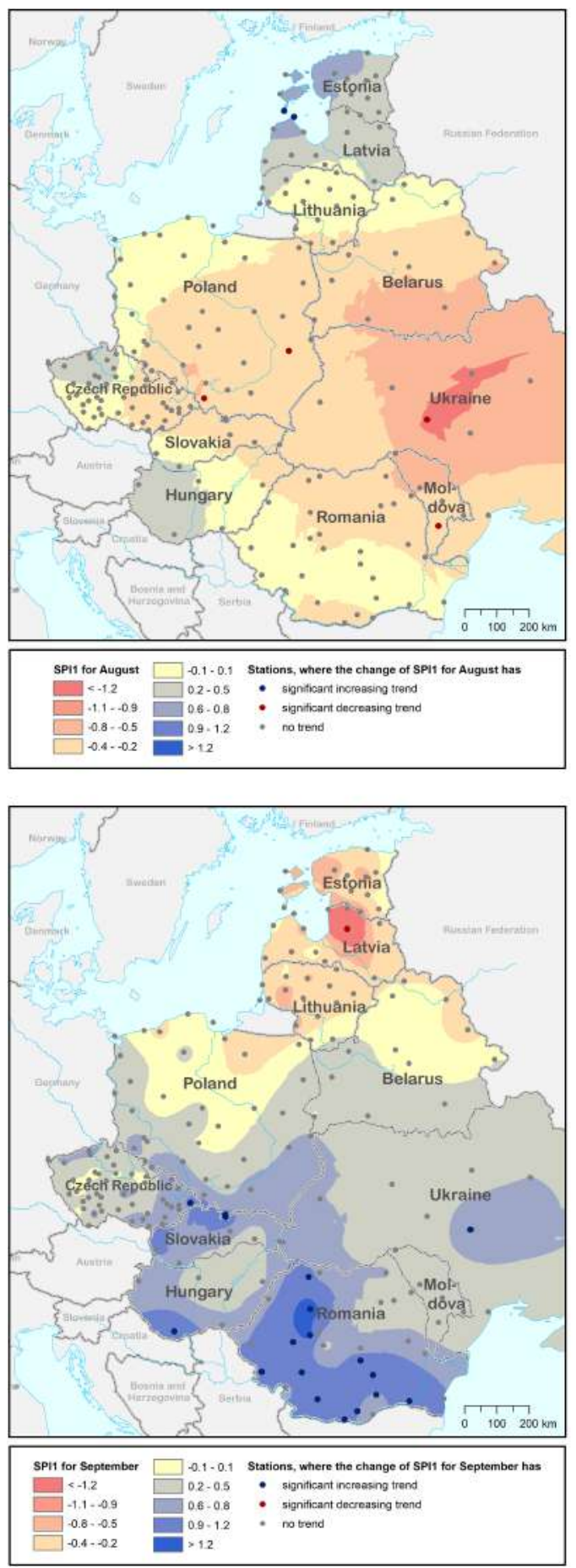

F I G URE 4 (Continued)

Differences between the net changes in SPI and SPEI are small (Figures $2 b$ and $3 a$ ).

The pattern of net changes in drought indices in spring is different for SPI and SPEI. The spring SPI3 shows significant increasing trends in many regionseastern Poland, south-western Belarus, western Ukraine and northern Latvia (Figure 2c). An insignificant decrease revealed in the Czech Republic and south-
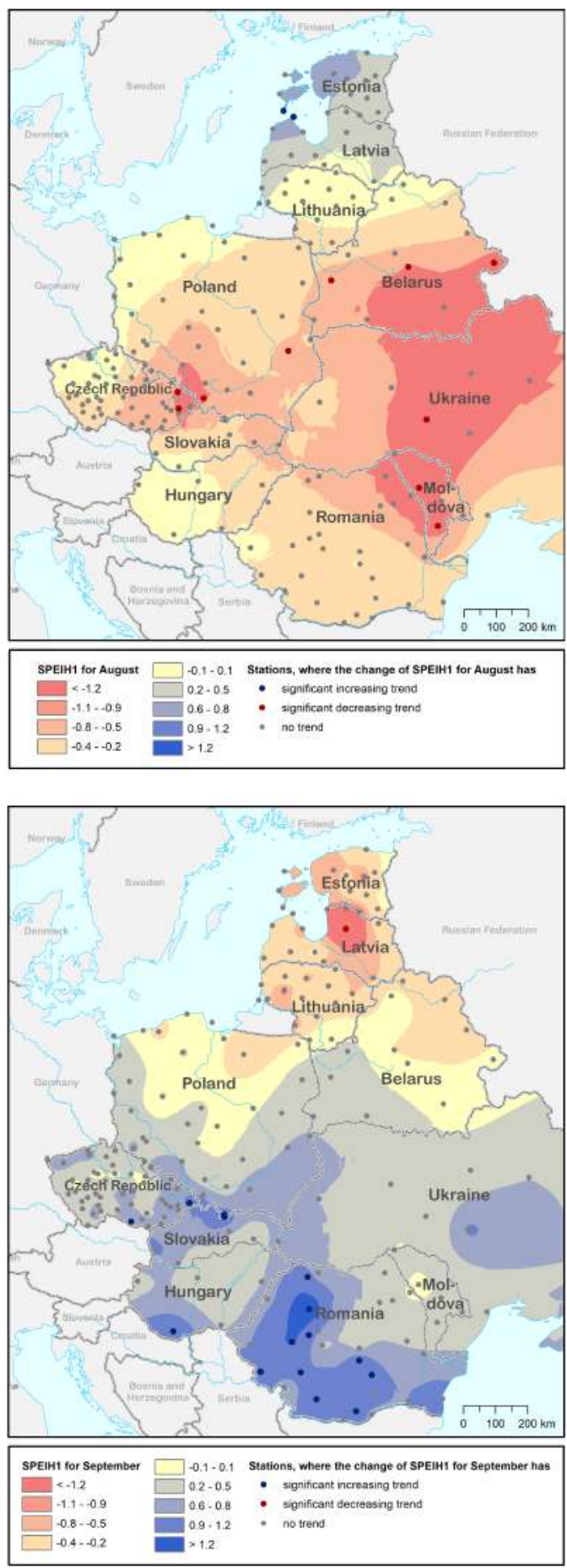

western Poland. At the same time, the spring SPEIH3 (Figure 2d) and SPEIP3 (Figure 3b) have no increasing trends while significant decreasing trends were seen in the Czech Republic, south-western Poland and Lithuania. The drying tendency due to the increase of AED in spring was widely evident all over the study region.

Changes in summer drought indices are dipole-like (Figures 2e,f and 3c). An increase is typical for the 
northernmost part of the study region (Estonia, Latvia, Lithuania) while, in some stations, it was statistically significant. At the same time, a decrease is evident in the southern regions, especially in the south-eastern part of the Czech Republic (Moravia) but also in Slovakia, Hungary, Moldova and Romania. The downward trend is stronger with SPEI in comparison with SPI, but this difference is still weaker than in spring.

No decreasing trends in drought indices were found in autumn (Figures 2g,h, 3d). The pattern can be characterized by a significant increase in the southern part of the study region, first of all, in Romania. Differences in the patterns
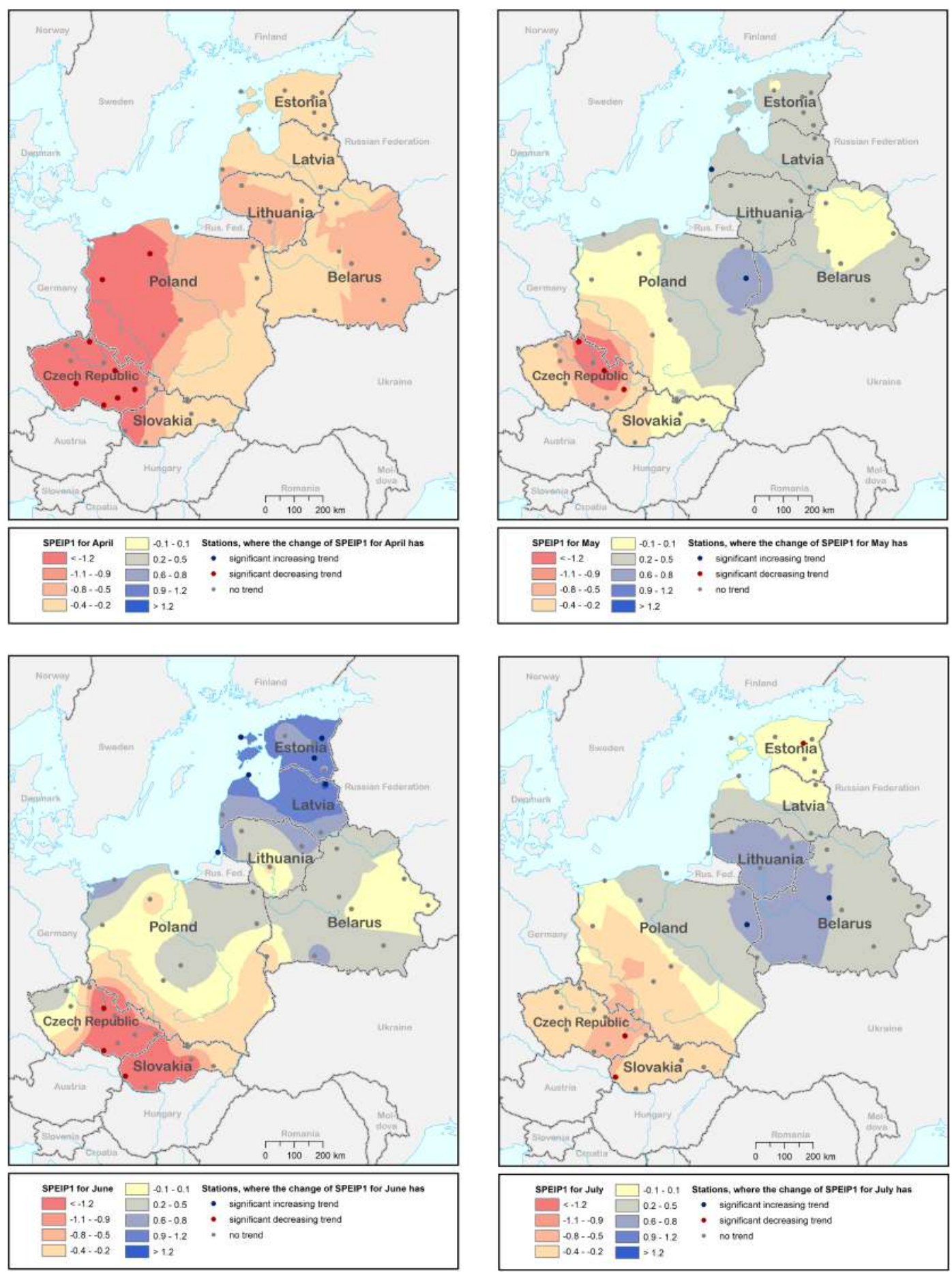

F I G U R E 5 Net changes in monthly SPEIP1 from 1949 to 2018 in April (a), SPEIP1 in May (b), SPEIP1 in June (c), SPEIP1 in July (d), SPEIP1 in August (e) and SPEIP1 in September (f) [Colour figure can be viewed at wileyonlinelibrary.com] 

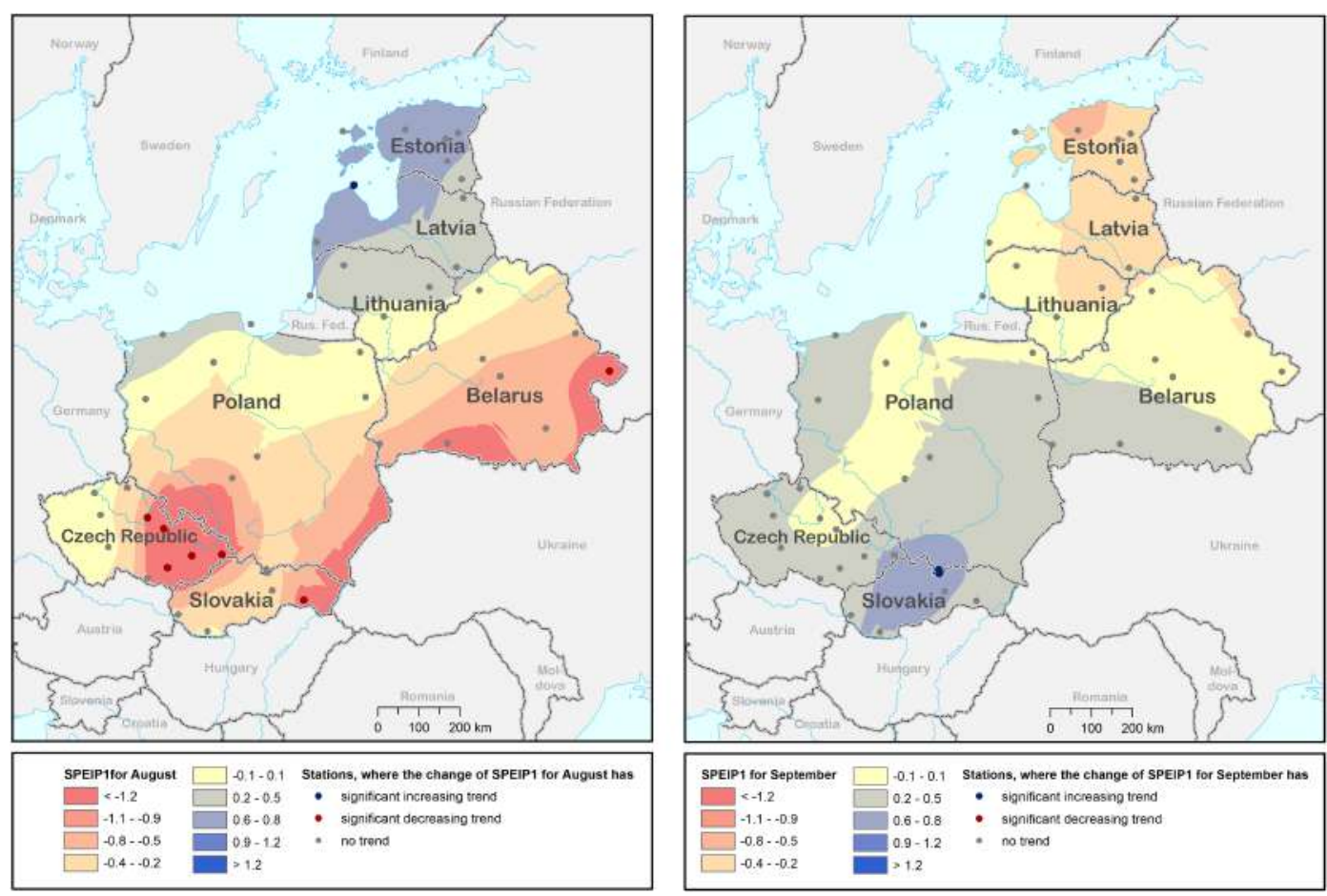

F IG URE 5 (Continued)

\begin{tabular}{lrrll} 
& SPI1 & SPEIH1 & SPI1-SPEIH1 & SPEIH1-SPEIP1 \\
\hline January & 0.45 & 0.37 & 0.08 & -0.07 \\
February & 0.14 & -0.09 & 0.23 & -0.05 \\
\hline March & 0.53 & 0.08 & 0.45 & -0.16 \\
\hline April & -0.21 & -0.47 & 0.26 & -0.04 \\
\hline May & 0.06 & -0.17 & 0.22 & -0.08 \\
\hline June & -0.02 & -0.12 & 0.10 & -0.07 \\
\hline July & 0.08 & -0.06 & 0.14 & 0.00 \\
August & -0.11 & -0.25 & 0.14 & -0.01 \\
\hline September & 0.25 & 0.23 & 0.02 & 0.00 \\
October & 0.59 & 0.59 & 0.01 & 0.00 \\
\hline November & -0.04 & -0.11 & 0.08 & -0.05 \\
\hline December & 0.07 & 0.03 & 0.04 & -0.02 \\
\hline
\end{tabular}

TABLE 1 Mean monthly net changes in the drought indices averaged over 182 stations and their differences

Note: In the last column, it is averaged over 46 stations.

of SPI3, SPEIH3 and SPEIP3 for November are not substantial.

\section{2 | Trends in monthly drought indices}

During the growing season, shorter droughts can significantly affect human activity, first of all agricultural production. Therefore, we have analysed long-term trends in monthly drought indices from April to September in more detail. Net changes in SPI1 and SPEIH1 are presented on Figure 4 and in SPEIP1 on Figure 5.

April could be characterized by a general drying tendency (Figures 4a,b and 5a). Statistically significant decreasing trends were detected mostly in the Czech Republic and in western part of Poland. Single stations with significant negative trend were detected also in western Slovakia, Hungary, Belarus, western Lithuania and western Latvia. In general, net changes of the drought indices for May show weak and insignificant 
trends (Figures 4c,d and 5b). Only some significant decreasing trends were recorded in the Czech Republic in SPEIH1 and in SPEIP1.

Trend values in drought indices in June were of the opposite sign in the study region (Figures 4e,f and 5c). The northernmost part (Estonia and northern Latvia) has a clear increasing trend related to the rise of rainfall. The highest decrease in drought indices in June was observed in the south-eastern part of the Czech Republic, western Slovakia and northern Hungary. There were few significant changes in drought indices during the midsummer month of July (Figures $4 \mathrm{~g}, \mathrm{~h}$ and $5 \mathrm{~d}$ ). Positive net changes were revealed in Lithuania, Belarus and northeastern Poland. The highest negative changes could be found in the eastern part of the Czech Republic, in Moravia.

August is the month which, together with April, expressed the strongest drying trend in central and eastern Europe. SPI did not show so many trends (Figure 4i) but SPEI had many more of them (Figures $4 \mathrm{j}$ and $5 \mathrm{e}$ ) due
F I G URE 6 Classification of stations into eight classes according to RPCA of net changes in monthly SPI and SPEIH [Colour figure can be viewed at wileyonlinelibrary.com]
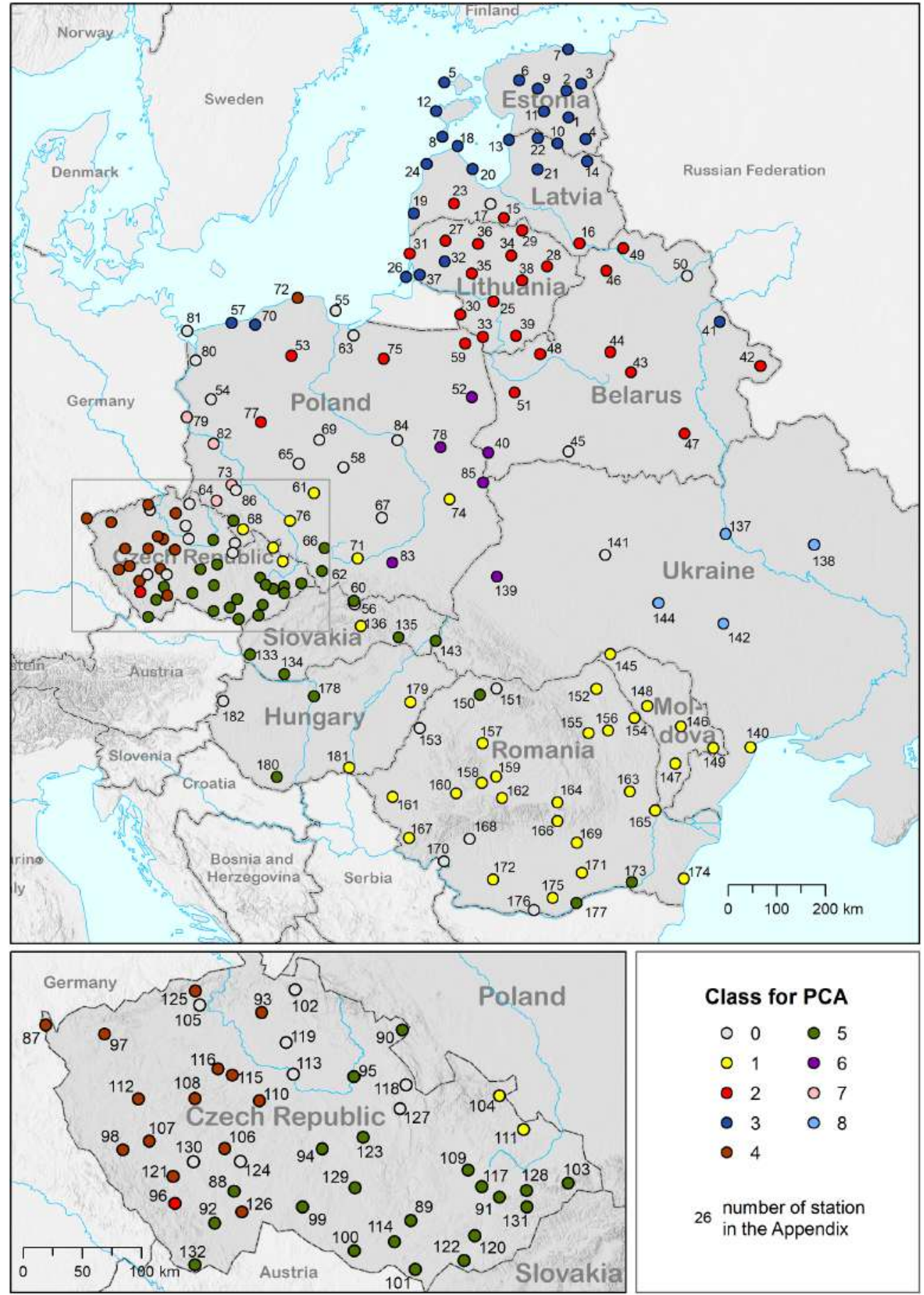

Class for PCA

$\circ$ ○ 05

$\circ 1 \bullet 6$

- 207

- 308

- 4

26 number of station in the Appendix 
TA B LE 2 Results of the RPCA and classification of stations: percentages of the PCs in total variance

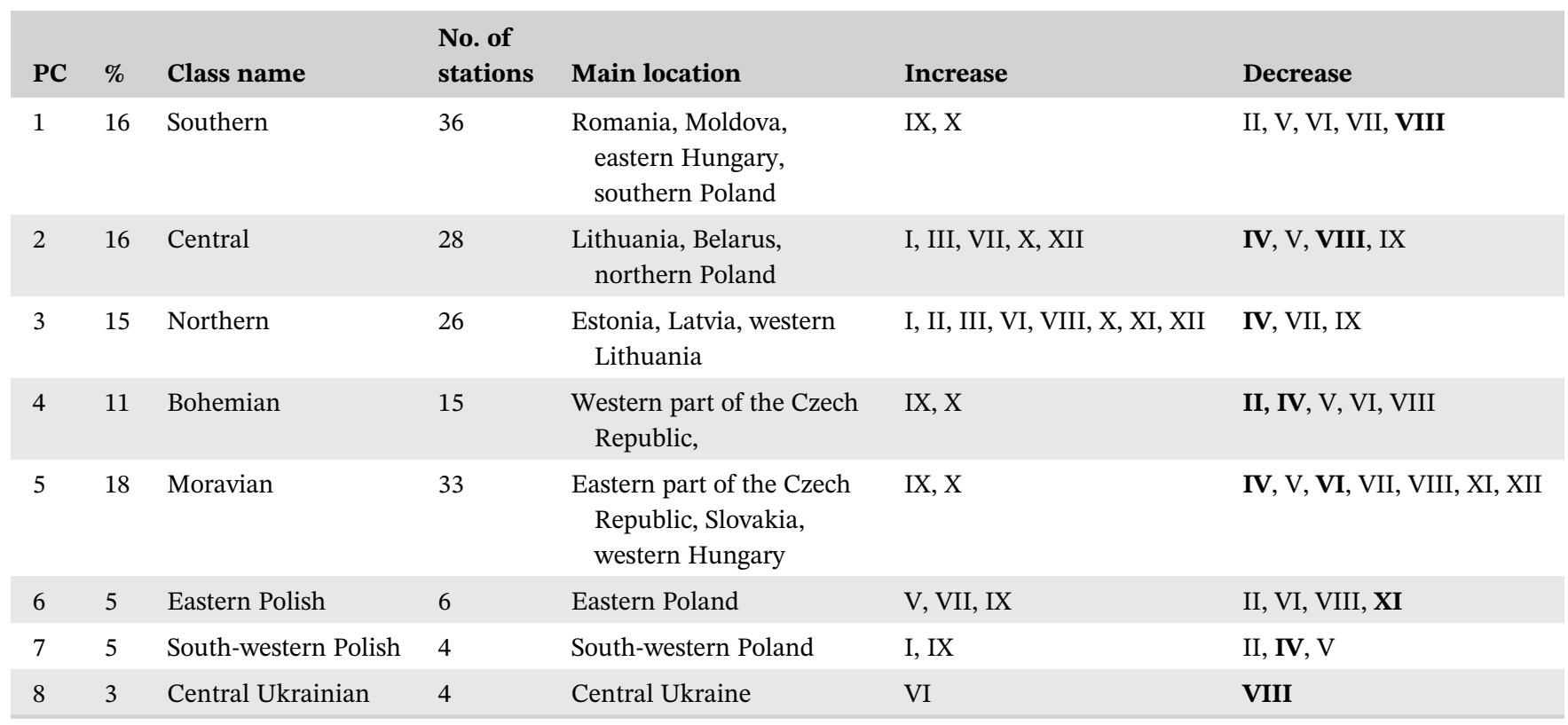

Notes: Number of stations in classes, main regions related to the PC, months with prevalent increasing and decreasing tendencies in SPI and SPEIH. Months with the most severe drying tendencies are typed in boldface.

to the taking into account the increase in AED caused by the general warming. The area of the statistically significant drying trend includes Ukraine, Moldova, southern Belarus, and the Silesia region in Poland and in the Czech Republic. Only the northernmost part of the study region, Estonia and northern Latvia, shows a weak insignificant increase in drought indices in August.

During September, the whole southern half of the study region had an increasing tendency in drought indices (Figures 4k,l and 5f). The strongest increase revealed in Romania where 13 stations have statistically significant trends in SPI1 for September. A weak and insignificant drying tendency was seen in the northern part of the region.

Monthly mean net changes in SPI1 and SPEIH1 averaged over the 182 stations are presented in Table 1. Mean values of the net changes in SPEIH1 are systematically lower than in SPI1. During the whole warm season from April to August, the mean net change in SPEIH1 was negative. This indicates that a drying tendency was prevailing in central and eastern Europe during that season in 1949-2018 if we take into account the increase in AED. The increasing trend in AED due to the increase in air temperature diminishes positive trends and enhances negative trends in SPEI, in comparison with SPI. This effect was the highest in spring and summer, and the lowest in autumn and winter. In the latter cases, AED was low and had only a small influence on the trends. Spring had the largest increase in temperature and, consequently, in AED. At the same time, AED is the highest in summer and its changes have a strong influence on changes in SPEI.

Comparing mean net changes in SPEIH and SPEIP, averaged over 46 stations (Table 1, last column), shows that differences were not large. Generally, SPEIH has slightly stronger decreasing trends than SPEIP, but not in summer and autumn. We should take into consideration that these differences vary a lot between stations. Consequently, trend values in the case of SPEIH and SPEIP are mostly the same.

\section{3 | Classification of stations}

The stations were classified into groups with similar net changes in monthly drought indices using the S-mode RPCA. The results for the 182 stations using monthly values of SPI and SPEIH allowed to determine eight groups or classes (Figure 6). The class 0 means a nonclassified station. All eight components describe $88 \%$ of total variance while five first components describe $75 \%$. Main results of the analysis are presented in Table 2.

The first PC (PC1) describes 16\% of the total variance. It is related to a wide area in the southern part of the study region with the southern class of stations. It includes Romania, Moldova, eastern Hungary and some stations in southern Poland. This region is described by a clear drying of the climate during the period from April till August. Decreasing trends are the strongest in August (Figure 7a); September and October have increasing trends in this region (Figure $7 b$ ). 

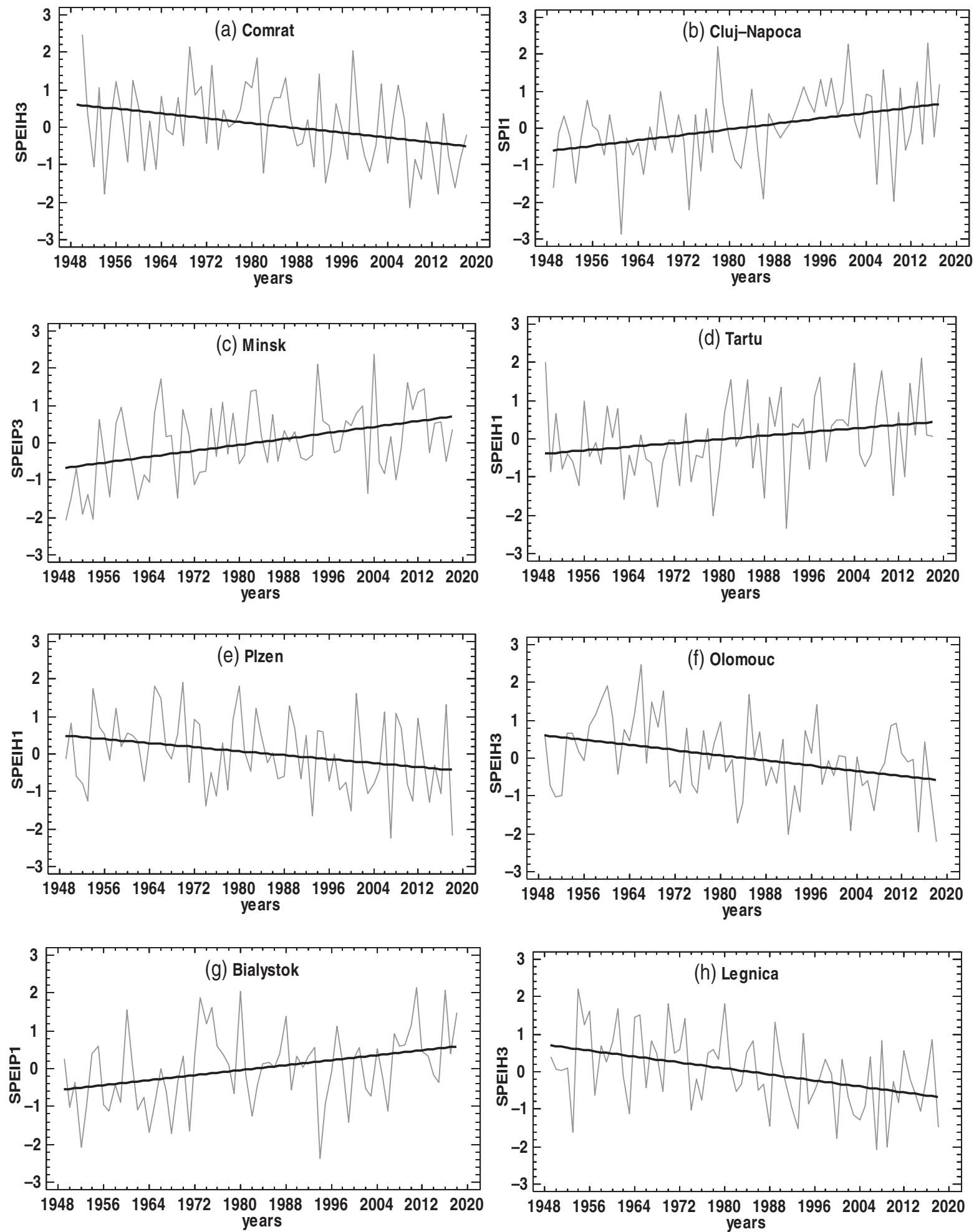

F I G U RE 7 Time series and linear trends of drought indices in 1949-2018: (a) SPEIH3 for August in Comrat related to PC1; (b) SPI1 for September in Cluj-Napoca (PC1); (c) SPEIP3 for February in Minsk (PC2); (d) SPEIH1 for June in Tartu (PC3); (e) SPEIH1 for April in Plzen (PC4); (f) SPEIH3 for August in Olomouc (PC5); (g) SPEIP1 for July in Białystok (PC6) and (h) SPEIH1 for April in Legnica (PC7). All these trends are statistically significant on the $p<.05$ level

The second group of stations, the central class, also describes $16 \%$ of the variance. It covers Belarus, Lithuania, southern Latvia and some stations in northern
Poland excluding the coastal stations. The stations of the central class are described by a strong increase during the cold season (Figure 7c) and a weak increase in July 
but also by remarkable decreasing tendencies in April, August and September.

The third group of stations, the northern class $(15.1 \%)$, is located in the northern end on the study region in Estonia, Latvia and western Lithuania. It also includes one station in Belarus and two coastal stations in Poland. Increasing trends in winter and in June (Figure 7d), as well as decreasing trends in April, July and September are specific for this group of stations. In the majority of cases, these changes are statistically insignificant.

The Czech Republic is divided into two main groups of stations. The fourth PC (10.7\%), called the Bohemian class, is related to the western part of the Czech Republic. The eastern part of the Czech Republic (Moravia) as well as Slovakia and western Hungary belong to the largest class of stations related to the PC5, describing the largest part of total variability (18\%). The strongest drying tendency is typical for these two classes; the main difference between them lies in much stronger decreasing tendencies in drought indices in the eastern group, where they were seen also in July, November and December. In the Bohemian class, a stronger drying tendency in the Bohemian class was found in spring (Figure 7e), while in the Moravian class in summer (Figure 7f).

In addition to these five large groups of stations, we defined three small classes: the eastern Polish, southwestern Polish and central Ukrainian classes. Although their part in total variance was less than 5\%, they formed clear regional units with their specific features in the net changes of drought indices. The eastern Polish class (PC6) consists of four stations in Poland plus Brest and Lviv stations. They are characterized by an increase in SPI and SPEI in July (Figure $7 \mathrm{~g}$ ) and a decrease in November. The south-western Polish group of stations is peculiar of its extremely strong decreasing trends in spring, especially in April (Figure 7h). The central Ukrainian class has mostly no significant trends.

\section{4 | DISCUSSION}

\subsection{Changes in the cold season}

During the cold season from November to March, the plant growth usually stops in central and eastern Europe. Drought indices in winter reflect only variations in precipitation. AED is very low during the cold season and can be neglected. Differences in the net changes of SPI and SPEI are minimal (Figures 2a,b and 3a). Trends in SPI and SPEI detected in our study directly reflect changes in the precipitation regime. At the same time, water availability in autumn and winter plays an important role in the formation of soil water sources in the next spring and summer.

Winter weather conditions in the study region are influenced by general climate warming (IPCC, 2013). Higher temperature in northern Europe is directly related to more frequent occurrence of cyclonic weather conditions described by higher cloudiness, wind speed and precipitation (Nawri, 2015). Warmer winters in Europe have been caused by a stronger westerly airflow, which is bringing comparatively warm maritime air mass from the North Atlantic far to the east up to the Ural Mountains (Hurrell, 1995; Ulbrich et al., 2009). In the southern part of the study region, most of precipitation is coming from the Mediterranean cyclones in winter (Trigo et al., 2000; Nissen et al., 2014). For example, the prevalence of westerly circulation is translated in Romania by less precipitation because of less Mediterranean cyclones (Busuioc and von Storch, 1996; Fleig et al., 2015).

High westerly circulation over northern and central Europe corresponds to the positive phase of the North Atlantic Oscillation (NAO). A clear increasing trend in the NAO index during the study period is closely related to the increase in winter air temperature and precipitation in the northern half of central and eastern Europe (Hurrell, 1995). Trends in SPI and SPEI reflect these changes.

Statistically significant increasing trends in SPI prevailed at the stations of the Baltic countries and northern Belarus during the cold season in 1949-2018. This result could be related to the temperature increase in winter, in which most of precipitation falls down in the form of rain, not of snow (e.g., Pecho et al., 2010). The amount of precipitation in rainfall is usually much higher than in snowfall. This is confirmed by recent studies in Belarus (Melnik et al., 2019).

The rise in winter rainfall is also partly due to the rise in temperature. According to Clausius-Clapeyron relation warmer air may contain more water vapour (Boer, 1993). Many studies indicate that this leads to higher extreme rainfall (Lenderink and van Meijgaard, 2008; Busuioc et al., 2016; Faško et al., 2018), but in the winter season it can also lead to higher median of daily totals (Wibig and Piotrowski, 2018).

At the same time, even a decrease in SPI and SPEI in some months of the cold season was mentioned in the southern half of the study region. Mostly, it was statistically insignificant. This tendency can be related to the negative correlation between NAO and precipitation in the southern Europe, especially in the Mediterranean region (Wibig, 1999).

Trends in winter drought indices in the three Baltic countries in 1949-2018 are very similar to those of precipitation, which were calculated for much shorter time 
frame-1966-2015 (Jaagus et al., 2018). At the majority of stations, the increasing trend was statistically significant in January, February and March, while in November and December the trend was significant only at a few stations. Increasing trends of precipitation in January, February and March were reported in many stations in Latvia in 1950-2003 (Briede and Lizuma, 2007). A similar increase in winter precipitation was detected also in Lithuania (Bukantis and Rimkus, 2005), and in northern and central Belarus (Partasenok et al., 2014). These changes in winter season are in a good correspondence with an increase in the cyclonic activity and a northward shift of the storm track in the Baltic Sea region (Sepp et al., 2005; Semenova and Sumak, 2017).

\section{2 | Changes in the warm season}

Drought indices during the warm season are in the main focus in this study. The hydrological regime of the cold season can have a noticeable influence on moisture availability and drought conditions only in the following spring and summer. Our general statement was that climate warming has made winter weather conditions more unstable in central and eastern Europe. It means higher temperature variations and more frequent melting periods. With mild winters, the spring water level maximum in rivers is much lower or might even be missing, and it occurs much earlier. In this case, a lack of soil moisture and drought conditions can form significantly earlier in spring than it has been usual (Jaagus et al., 2017).

Our analysis of long-term changes in drought indices demonstrated that there has been a general drying tendency in April. Statistically significant changes in SPI1 were detected in some stations in southern Poland and in the Czech Republic. The strongest trends were revealed for SPEIH1 when significant decreasing changes in April were found at 17 stations in the Czech Republic, at 10 stations in Poland, and also at one station in Belarus, Lithuania and Latvia. This change can be explained by the decrease in precipitation and partly by the increase in AED due to higher temperature in April. The decreasing tendency in April precipitation was earlier mentioned in Estonia (Jaagus et al., 2017), Latvia (Briede and Lizuma, 2007), in the Nemunas River Basin (Stonevičus et al., 2018) and in Poland (Somorowska, 2016).

Such a strong trend in April may result from the disappearance of the continuous snow cover in the lowlands area in winter. The air temperature raises faster because of lower albedo (less snow cover) and less energy is used to melt the snow. At the same time the lack of an injection of moisture from the melting snow causes the air to be drier and the total precipitation lower.
It is interesting that Romania and Moldova had no decreasing changes in April drought indices. Conversely, the remote sensing soil moisture indices (Potopová et al., 2020) showed that the soil moisture content had decreased below the optimal condition in April and May. As a result, the spring water balance did not replenish soil water content levels after the sowing summer crops in the Republic of Moldova.

May is the month that had very few significant changes in the drought indices during the 70 years under study. Only some decreasing trends were found in SPEIH1 and SPEIP1 in the Czech Republic. It is interesting to mention that the highest differences between the net changes in SPI and SPEI were observed in spring, not in summer. Comparing of the change patterns of SPI3 (Figure 2c) and SPEIH3 (Figure 2d) for May shows substantial differences, which are remarkably higher than the differences between changes in SPI3 (Figure 2e) and SPEIH3 (Figure 2f) for August.

The use of SPEI, instead of SPI, for the analysis of long-term changes in drought conditions is much more justified because it takes into account changes in AED as well. Due to the increase in air temperature, AED has increased, initiating the climate drying tendency. Our results show that the increase in AED in the northern part of the study area has been more substantial just in spring than in summer.

Drought indices for June clearly exhibit trends of the opposite sign. A statistically significant increase in Estonia coincided with a significant decrease in the Czech Republic and at some other stations. It is directly related to the increase in precipitation in Estonia (Jaagus et al., 2018) and its decrease in the southern regions. There is an interesting belt of a stronger drying tendency over Poland, stretching from the south-west to the northeast up to Lithuania and Belarus (Figure 4e,f).

July also has different changes in different regions, but very few significant trends were detected. An increase in Lithuania and Belarus is related to the increase in precipitation. Surprisingly, a weak decreasing tendency was seen at many stations in Estonia. The most remarkable drying tendency in SPEIH1 in July was found in the southern regions, first of all in the eastern part of the Czech Republic. The increase in AED due to the increase in temperature probably plays an important role.

SPI and SPEI in August can be described with the prevailing of a drying tendency. Again, it is the most remarkable in the central and southern regions of the study area indicating a real climatic change. A temperature increase has led to the increase in the drought risk in August. The only exceptions are Estonia and Latvia where the drought indices have a weak increasing tendency. Here, the increase in precipitation is not compensated by the increase in AED. 
SPI and SPEI in August can be described with the prevailing of a drying tendency. Again, it is the most remarkable in the central and southern regions of the study area indicating a real climatic change. A temperature increase has led to the increase in the drought risk in August. The only exceptions are Estonia and Latvia where the drought indices have a weak increasing tendency. Here, the increase in precipitation is not compensated by the increase in AED.

It is interesting to mention that the persistent multiyear drought in central Europe during 2014-2019 affected different regions during different seasons. Conversely, the countries in south-eastern Europe were less affected by drought; however, the prevailing wet period during 2016-2019 was not nearly enough to erase the rainfall deficit that had accumulated over the previous decade (Potopová et al., 2019, 2020). Based on the compound climate events and yield losses (Zscheischler et al., 2018; Potopová et al., 2021), 2018 may be considered the new reference year for hotter droughts in Europe.

In conclusion, our study demonstrated that the most severe climate drying trends in eastern and central Europe during the growing season in 1949-2018 took place not in the southernmost region in Romania but in the Czech Republic, especially in its eastern part (Moravia), mainly in spring and summer, when AED has an important contribution.

\section{3 | Classification of stations}

RPCA is an appropriate tool for classification of stations and for regionalization. We successfully classified the stations used in this study into five large and three small groups based on the similarity of their net changes in drought indices. Three large classes-the southern, central and northern-reflect meridional differences in the changes of moisture conditions. The northern class with the prevalent increase in drought indices, especially during the cold half-year, and the southern class presenting more decreasing tendencies, first of all during the growing season, express opposite fluctuations in precipitation in northern and southern Europe induced by the North Atlantic Oscillation.

Separation of the Bohemian and Moravian classes in the Czech Republic is caused by the fact that about one third of all stations, used in this study, are located in this country. They are the sources of a large share in total variability, which is mostly described by these two components (PC4 and PC5). We assume that drought conditions might vary greatly in the Czech Republic due to the high variability in topography and landscape features. The strongest decreasing trends in drought indices were found in the Czech Republic, especially in the Moravian class of stations (PC5).

We suggested that it will be reasonable to define also three small classes of stations, which reflect smaller regional differences in the net changes of SPI1 and SPEIH1. These areas have a lower density of stations, like in Ukraine, because their changes in drought indices might be typical for quite a wide territory.

Based on the classification of stations we can conclude that the most complicated pattern of the net changes of SPI and SPEI was observed on the territory of Poland located in the central part of the study region. Its climate is transitional between the north and the south as well as the east and the west of studied area. Stations located at the seaside have moisture regime similar to those in the Estonia. Stations located at the central part of the southern Poland have moisture regime similar to those located in Romania. Northern stations are similar to those in Lithuania and northern part of Belarus, submountain stations have Moravian regime. There are also two small typical Polish classes, one located along western and the other along eastern boundary. Additionally one-third of the stations, those located in the central part of the country, were not included in any class, because their moisture regime were equally similar to at least two classes. It indicates that the moisture regime in different parts of Poland is determined by the influence of very different factors.

\section{5 | CONCLUSIONS}

We generally found that the drought conditions in central and eastern Europe have been stable during 1949-2018. There have been no overall changes during the growing season lasting from April to October, while some statistically significant trends were detected in certain regions.

Changes in drought indices during the cold season (November-March) show significant increasing trends in the northern part of the study region, that is, in Estonia, Latvia, Lithuania and northern Belarus, reflecting a general increase in precipitation. The rest of the study region does not exhibit significant changes in SPI and SPEI in the cold season.

Summer season and summer months June, July and August are characterized by changes of the opposite sign in drought indices between the northern and other parts of the study region. The increase in SPEI, that is, a decrease in the drought conditions has prevailed in the north, in the Baltic countries and in northern Belarus, while a clear decrease in SPEI and an increase of drought has been typical for the central and southern regions, first of all in the Czech Republic, Romania, Moldova and 
southern Poland. The station density in Ukraine, Slovakia and Hungary was not sufficient to determine such a clear spatial pattern but our data still indicate the prevalence of the drying tendency in these countries as well.

A general drying tendency was revealed in April, which was statistically significant in the Czech Republic and Poland, but it dominated over the whole study region. At the same time, increasing trends in SPI and SPEI for September and October were detected in Romania, Moldova and Hungary, which reflect an increase in precipitation in this region.

The use of SPEI instead of SPI enhances decreasing trends and diminishes increasing trends due to the taking into account the increase in AED caused by warming particularly during the warm season. Changes in SPEIH and SPEIP were practically similar, reinforcing the main role of the temperature increase to explain changes in the AED.

The classification of the stations by similar net changes in monthly drought indices using the RPCA distinguished five large classes-the southern (centred in Romania and Moldova), central (Belarus, Lithuania and Poland), northern (Estonia and Latvia), eastern (Moravian) and western (Bohemian) Czech groups-and three small ones-the eastern Polish, south-western Polish and central Ukrainian classes.

\section{ACKNOWLEDGEMENTS}

This study was initiated and financed by the EU JPI WATER project IMDROFLOOD. In addition, it is partly supported by the Ministry of Education and Research of Estonia (grant PRG-352), by the projects "SustESAdaptation strategies for sustainable ecosystem services and food security under adverse environmental conditions" (ref. CZ.02.1.01/0.0/0.0/16_019/0000797), MZe QK1910269 "Adaptation potential of common wheat in response to drought and extreme temperatures," and by DAMOCLES COST ACA17109 "Understanding and modelling compound climate and weather events" (2018-2022).

\section{AUTHOR CONTRIBUTIONS}

Jaak Jaagus: Conceptualization; data curation; formal analysis; funding acquisition; investigation; methodology; project administration; resources; supervision; validation; writing-original draft; writing-review \& editing. Anto Aasa: Data curation; formal analysis; investigation; methodology; software; writing-review \& editing. Svetlana Aniskeviča: Data curation; resources; writingreview \& editing. Boris Boincean: Data curation; resources; writing-review \& editing. Roxana Bojariu: Conceptualization; data curation; funding acquisition; resources; writing-review \& editing. Agrita Briede: Data curation; resources; writing-review \& editing. Irina Danilovich: Data curation; formal analysis; resources; writing-review \& editing. F Dominguez-Castro: Conceptualization; formal analysis; investigation; methodology; project administration; software; writing-review \& editing. Alexandru Dumitrescu: Data curation; formal analysis; resources; writing-review \& editing. Martin Labuda: Data curation; resources; writing-review \& editing. Livia Labudova: Data curation; resources; writing-review \& editing. Krista Lõhmus: Formal analysis; investigation; methodology; writing-review \& editing. Viktar Melnik: Data curation; resources; writingreview \& editing. Kiira Mõisja: Visualization; writingreview \& editing. Rita Pongracz: Data curation; resources; writing-review \& editing. Vera Potopová: Data curation; resources; writing-review \& editing. Ladislava Reznickova: Data curation; resources; writing-review \& editing. Egidijus Rimkus: Data curation; resources; writing-review \& editing. Inna Semenova: Data curation; resources; writing-review \& editing. Edvinas Stonevičius: Data curation; resources; writing-review \& editing. Petr Stepanek: Data curation; formal analysis; methodology; resources; software; writing-review \& editing. Miroslav Trnka: Data curation; resources; writing-review \& editing. Sergio VicenteSerrano: Conceptualization; funding acquisition; methodology; project administration; supervision; writingreview \& editing. Joanna Wibig: Data curation; formal analysis; resources; writing-review \& editing. Pavel Zahradnicek: Data curation; formal analysis; methodology; resources; software; writing-review \& editing.

\section{ORCID}

Jaak Jaagus (1) https://orcid.org/0000-0002-6617-9125 Alexandru Dumitrescu (D) https://orcid.org/0000-00023361-483X

Vera Potopová (1) https://orcid.org/0000-0002-2723-0397

Petr Štěpánek (10 https://orcid.org/0000-0001-8956-5590

Miroslav Trnka (1) https://orcid.org/0000-0003-4727-8379

Sergio M. Vicente-Serrano (1D https://orcid.org/0000-0003-

2892-518X

Joanna Wibig (1) https://orcid.org/0000-0002-8560-0325

Pavel Zahradníček (1) https://orcid.org/0000-0003-3978-

5653

\section{REFERENCES}

Allen, C.D., Breshears, D.D. and McDowell, N.G. (2015) On underestimation of global vulnerability to tree mortality and forest die-off from hotter drought in the Anthropocene. Ecosphere, 6 (8), art129. https://doi.org/10.1890/ES15-00203.1.

Allen, R.G., Pereira, L.S., Raes, D. and Smith, M. (1998) Crop evapotranspiration-guidelines for computing crop water requirements. FAO Irrigation and Drainage Paper, 56. 
Anders, I., Stagl, J., Auer, I. and Pavlik, D. (2014) Climate change in central and eastern Europe. In: Rannow, S. and Neubert, M. (Eds.) Managing protected areas in central and eastern Europe under climate change, Vol. 58. Dordrecht: Advances in Global Change Research, Springer.

Bachmair, S., Tanguy, M., Hannaford, J. and Stahl, K. (2018) How well do meteorological indicators represent agricultural and forest drought across Europe? Environmental Research Letters, 13, 034042.

Boer, G. (1993) Climate change and the regulation of the surface moisture and energy budgets. Climate Dynamics, 8, 225-239.

Briede, A. and Lizuma, L. (2007) Long-term variability of precipitation in the territory of Latvia. In: Kḷaviņšs, M. (Ed.) . Climate change in Latvia, pp. 35-44.

Bukantis, A. and Rimkus, E. (2005) Climate variability and change in Lithuania. Acta Zoologica Litaunica, 15, 100-104.

Busuioc, A., Birsan, M.V., Carbunaru, D., Baciu, M. and Orzan, A. (2016) Changes in the large-scale thermodynamic instability and connection with rain shower frequency over Romania: verification of Clausius-Clapeyron scaling. International Journal of Climatology, 36, 2015-2034.

Busuioc, A. and von Storch, H. (1996) Changes in the winter precipitation in Romania and its relation to the large-scale circulation. Tellus, 48A, 538-552.

Danilovich, I., Zhuravlev, S., Kurochkina, L. and Groisman, P. (2019) The past and future estimates of climate and streamflow changes in the Western Dvina River basin. Frontiers in Earth Science, 7, 204. https://doi.org/10.3389/feart.2019.00204.

Dumitrescu, A., Bojariu, R., Birsan, M.V., Marin, L. and Manea, A. (2015) Recent climatic changes in Romania from observational data (1961-2013). Theoretical and Applied Climatology, 122, 111-119.

Faško, P., Kajaba, P., Markovič, L. and Pecho, J. (2018) Trends in heavy precipitation in Slovakia over 1951-2017. EMS Annual Meeting Abstracts, 15.

Fleig, A.K., Tallaksen, L.M., James, P., Hisdal, H. and Stahl, K. (2015) Attribution of European precipitation and temperature trends to changes in synoptic circulation. Hydrology and Earth System Sciences, 19, 3093-3107.

García-Herrera, R., Paredes, D., Trigo, R.M., Trigo, I.F., Hernández, E., Barriopedro, D. and Mendes, M.A. (2007) The outstanding 2004/05 drought in the Iberian Peninsula: associated atmospheric circulation. Journal of Hydrometeorology, 8, 483-498.

García-Herrera, R., Garrido-Pérez, J.M., Barriopedro, D., Ordóñez, C., Vicente-Serrano, S.M., Nieto, R., Gimeno, L., Sorí, R. and Yiou, P. (2019) The European 2016/2017 drought. Journal of Climate, 32, 3169-3187.

Hargreaves, G.H. and Samani, Z.A. (1982) Estimating potential evapotranspiration. Journal of the Irrigation and Drainage Division, 108, 225-230.

Hari, V., Rakovec, O., Markonis, Y., Hanel, M. and Kumar, R. (2020) Increased future occurrences of the exceptional 20182019 Central European drought under global warming. Scientific Reports, 10, 12207. doi.org/10.1038/s41598-020-68872-9.

Heim, R.R. (2002) A review of twentieth-century drought indices used in the United States. Bulletin of the American Meteorological Society, 83, 1149-1165.

Hurrell, J.W. (1995) Decadal trends in the North Atlantic oscillation: regional temperatures and precipitation. Science, 269, 676-679.
IPCC. (2013) Climate change 2013: the physical science basis. In: Contribution of Working Group I to the Fifth Assessment Report of the Intergovernmental Panel on Climate Change. Cambridge and New York: Cambridge University Press.

Jaagus, J., Briede, A., Rimkus, E. and Sepp, M. (2018) Changes in precipitation regime in the Baltic countries in 1966-2015. Theoretical and Applied Climatology, 131, 433-443.

Jaagus, J., Sepp, M., Tamm, T., Järvet, A. and Mõisja, K. (2017) Trends and regime shifts in climatic conditions and river runoff in Estonia during 1951-2015. Earth Systems Dynamics, 8, 963-976.

Kendall, M.G. (1975) Rank Correlation Methods. London: Griffin.

Kingston, D.G., Stagge, J.H., Tallaksen, L.M. and Hannah, D.M. (2015) European-scale drought: Understanding connections between atmospheric circulation and meteorological drought indices. Journal of Climate, 28, 505-516.

Klein Tank, A.M.G., Wijngaard, J.B., Können, G.P., Böhm, R., Demaree, G., Gocheva, A., Mileta, M., Pashiardis, S., Hejkrlik, L., Kern-Hansen, C., Heino, R., Bessemoulin, P., Müller-Westermeier, G., Tzanakou, M., Szalai, S., Palsdottir, T., Fitzgerald, D., Rubin, S., Capaldo, M., Maugeri, M., Leitass, A., Bukantis, A., Aberfeld, R., Van Engelen, A.F.V., Førland, E., Mietus, M., Coelho, F., Mares, C., Razuvaev, V., Nieplova, E., Cegnar, T., Lopez, J.A., Dahlström, B., Moberg, A., Kirchhofer, W., Ceylan, A., Pachaliuk, O., Alexander, L.V. and Petrovic, P. (2002) Daily dataset of 20th-century surface air temperature and precipitation series for the European Climate Assessment. International Journal of Climatology, 22, 1441-1453.

Labudová, L., Labuda, M. and Takáč, J. (2017) Comparison of SPI and SPEI applicability for drought impact assessment on crop production in the Danubian Lowland and the East Slovakian Lowland. Theoretical and Applied Climatology, 128, 491-506.

Lenderink, G. and van Meijgaard, E. (2008) Increase in hourly precipitation extremes beyond expectations from temperature changes. Nature Geoscience, 1, 511-514.

Leuzinger, S., Zotz, G., Asshoff, R. and Korner, C. (2005) Responses of deciduous forest trees to severe drought in Central Europe. Tree Physiology, 25, 641-650.

Mann, H.B. (1945) Nonparametric tests against trend. Econometrica, 13, 245-259.

McKee, T.B., Doesken, N.J. and Kleist, J. (1993) The relationship of drought frequency and duration to time scales. Preprints. In: Eighth Conference on Applied Climatology. Anaheim, CA: American Meteorological Society, pp. 179-184.

Melnik, V.I., Buyakov, I.V. and Chernyshev, V.D. (2019) Changes in the amount and type of precipitation in the cold period in the territory of Belarus under conditions of modern climate warming. Nature Management, 2, 44-51 (in Russian. summary in English).

Moore, F.C. and Lobell, D.B. (2015) The fingerprint of climate trends on European crop yields. Proceedings of the National Academy of Sciences of the United States of America, 112, 26702675.

Mukherjee, S., Mishra, A. and Trenberth, K.E. (2018) Climate change and drought: a perspective on drought indices. Current Climate Change Reports, 4(2), 145-163.

Nawri, N. (2015) Cyclones and Associated Weather Patterns over the Northern North Atlantic Region Based on ECMWF Reanalyses. VÍ Report. Reykjavík: Icelandic Met Office. https://www.vedur. is/media/vedurstofan/utgafa/skyrslur/2015/VI_2015_005.pdf. 
NDMC. (2021) Types of Drought. Lincoln: National Drought Mitigation Centre, University of Nebraska. https://drought.unl.edu/ Education/DroughtIn-depth/TypesofDrought.aspx.

Nissen, K.M., Leckebusch, G.C., Pinto, J.G. and Ulbrich, U. (2014) Mediterranean cyclones and windstorms in a changing climate. Regional Environmental Change, 14, 1873-1890.

Orlowsky, B. and Seneviratne, S.I. (2013) Elusive drought: uncertainty in observed trends and short-and long-term CMIP5 projections. Hydrology and Earth System Sciences, 17, 1765-1781.

Partasenok, I.S., Groisman, P.Y., Chekan, G.S. and Melnik, V.I. (2014) Winter cyclone frequency and following freshet streamflow formation on the rivers in Belarus. Environmental Research Letters, 9, 095005. https://doi.org/10.1088/1748-9326/9/9/095005.

Pecho, J., Faško, P., Mikulová, K., Štastný, P., Nejedlík, P. and Košlálová, J. (2010): Comparative analysis of selected snow cover characteristics in Slovakia within the 1950/19511979/1980 and 1980/1981-2009/2010 winters. Presented at 7th EGU General Assembly, Vienna, 2nd-7th May 2010.

Potopová, V., Boroneanţ, C., Boincean, B. and Soukup, J. (2016) Impact of agricultural drought on main crop yields in the Republic of Moldova. International Journal of Climatology, 36, 2063-2082.

Potopová, V., Cazac, V., Boincean, B., Soukup, J. and Trnka, M. (2019) Application of hydroclimatic drought indicators in the transboundary Prut River basin. Theoretical and Applied Climatology, 137, 3102-3121.

Potopová, V., Lhotka, O., Možný, M. and Musiolková, M. (2021) Vulnerability of hop-yields due to compound drought and heat events over European key-hop regions. International Journal of Climatology, 41(S1), E2136-E2158. https://doi.org/10.1002/joc.6836.

Potopová, V., Trnka, M., Hamouz, P., Soukup, J. and Castraveț, T. (2020) Statistical modelling of drought-related yield losses using soil moisture-vegetation remote sensing and multiscalar indices in the south-eastern Europe. Agricultural Water Management, 236, 106168. https://doi.org/10.1016/j.agwat.2020.106168.

Richman, M.B. (1986) Rotation of principal components. Journal of Climatology, 6, 293-335.

Rimkus, E., Valiukas, D., Kažys, J., Gečaitè, I. and Stonevičius, E. (2012) Dryness dynamics of the Baltic Sea region. Baltica, 25(2), 129-142.

Rita, A., Camarero, J.J., Nolè, A., Borghetti, M., Brunetti, M., Pergola, N., Serio, C., Vicente-Serrano, S.M., Tramutoli, V. and Ripullone, F. (2019) The impact of drought spells on forests depends on site conditions: the case of 2017 summer heat wave in southern Europe. Global Change Biology, 26, 851-863.

Semenova, I. and Sumak, K. (2017) Cyclonic activity in cold season over territories of Belarus and Ukraine and its relation to the warm season droughts. Croatian Meteorological Journal, 52, 59-73.

Sen, P.K. (1968) Estimates of the regression coefficient based on Kendall's tau. International Journal of American Statistical Association, 63, 1379-1389.

Sepp, M., Post, P. and Jaagus, J. (2005) Long-term changes in the frequency of cyclones and their trajectories in Central and Northern Europe. Nordic Hydrology, 36, 297-309.

Somorowska, U. (2016) Changes in drought conditions in Poland over the past 60 years evaluated by the Standardized Precipitation-Evapotranspiration Index. Acta Geophysica, 64, 2530-2549.
Spinoni, J., Naumann, G. and Vogt, J.V. (2017) Pan-European seasonal trends and recent changes of drought frequency and severity. Global and Planetary Change, 148, 113-130.

Spinoni, J., Vogt, J.V., Naumann, G., Barbosa, P. and Dosio, A. (2018) Will drought events become more frequent and severe in Europe? International Journal of Climatology, 38, 1718-1736.

Spinoni, J., Barbosa, P., De Jager, A., McCormick, N., Naumann, G., Vogt, J.V., Magni, D., Masante, D. and Mazzeschi, M. (2019) A new global database of meteorological drought events from 1951 to 2016. Journal of Hydrology: Regional Studies, 22, 100593.

Spinoni, J., Barbosa, P., Bucchignani, E., Cassano, J., Cavazos, T., Christensen, J.H., Christensen, O.B., Coppola, E., Evans, J., Geyer, B., Giorgi, F., Hadjinicolaou, P., Jacob, D., Katzfey, J., Koenigk, T., Laprise, R., Lennard, C.J., Levent Kurnaz, M., Li, D., Llopart, M., McCormick, N., Naumann, G., Nikulin, G., Ozturk, T., Panitz, H.-J., Porfirio da Rocha, R., Rockel, B., Solman, S.A., Syktus, J., Tangang, F., Teichmann, C., Vautard, R., Vogt, J.V., Winger, K., Zittis, G. and Dosio, A. (2020) Future global meteorological drought hot spots: a study based on CORDEX data. Journal of Climate, 33, 3635-3661.

Stillman, S., Zeng, X. and Bosilovich, M.G. (2016) Evaluation of 22 precipitation and 23 soil moisture products over a semiarid area in Southeastern Arizona. Journal of Hydrometeorology, 17, 211-230.

Stonevičus, E., Rimkus, E., Kažys, J., Bukantis, A., Kriaučiūnienė, J., Akstinas, V., Jakimavičius, D., Povilaitis, A., Ložys, L., Kesminas, V., Virbickas, T. and Pliūraitè, V. (2018) Recent aridity trends and future projections in the Nemunas River basin. Climate Research, 75, 143-154.

Szwed, M., Karg, G., Pińskwar, I., Radziejewski, M., Graczyk, D., Kędziora, A. and Kundzewicz, Z.W. (2010) Climate change and its effect on agriculture, water resources and human health sectors in Poland. Natural Hazards and Earth System Sciences, 10, 1725-1737.

Štěpánek, P., Zahradníček, P. and Huth, R. (2011) Interpolation techniques used for data quality control and calculation of technical series: an example of central European daily time series. Idöjárás, 115, 87-98.

Štěpánek, P., Zahradníček, P. and Farda, A. (2013) Experiences with data quality control and homogenization of daily records of various meteorological elements in the Czech Republic in the period 1961-2010. Idöjárás, 117, 123-141.

Trigo, I.F., Davies, T.D. and Bigg, G.R. (2000) Decline in Mediterranean rainfall caused by weakening of Mediterranean cyclones. Geophysical Research Letters, 27, 2913-2916. https://doi.org/10. 1029/2000GL011526.

Trnka, M., Balek, J., Štěpánek, P., Zahradníček, P., Možný, M., Eitzinger, J., Žalud, Z., Formayer, H., Turňa, M., Nejedlík, P., Semerádová, D., Hlavinka, P. and Brázdil, R. (2016) Drought trends over part of Central Europe between 1961 and 2014. Climate Research, 70, 143-160.

Ulbrich, U., Leckebusch, G.C. and Pinto, J.G. (2009) Extra-tropical cyclones in the present and future climate: a review. Theoretical and Applied Climatology, 96, 117-131.

Van Loon, A.F., Ploum, S.W., Parajka, J., Fleig, A.K., Garnier, E., Laaha, G. and Van Lanen, H.A.J. (2015) Hydrological drought types in cold climates: quantitative analysis of causing factors and qualitative survey of impacts. Hydrology and Earth System Sciences, 19, 1993-2016. 
Vicente-Serrano, S.M., Beguería, S. and López-Moreno, J.I. (2010) A multiscalar drought index sensitive to global warming: the standardized precipitation evapotranspiration index. Journal of Climate, 23, 1696-1718.

Vicente-Serrano, S.M., Lopez-Moreno, J.-I., Beguería, S., LorenzoLacruz, J., Sanchez-Lorenzo, A., García-Ruiz, J.M., AzorinMolina, C., Moran-Tejeda, E., Revuelto, J., Trigo, R., Coelho, F. and Espejo, F. (2014) Evidence of increasing drought severity caused by temperature rise in southern Europe. Environmental Research Letters, 9, 44001-44009. https://doi.org/10.1088/1748-9326/9/4/044001.

Vicente-Serrano, S.M., García-Herrera, R., Barriopedro, D., AzorinMolina, C., López-Moreno, J.I., Martín-Hernández, N., TomásBurguera, M., Gimeno, L. and Nieto, R. (2016) The Westerly Index as complementary indicator of the North Atlantic oscillation in explaining drought variability across Europe. Climate Dynamics, 47, 845-863.

Vicente-Serrano, S.M., Nieto, R., Gimeno, L., Azorin-Molina, C., Drumond, A., El Kenawy, A., Domínguez-Castro, F., TomásBurguera, M. and Peña-Gallardo, M. (2018) Recent changes of relative humidity: regional connections with land and ocean processes. Earth System Dynamics, 9, 915-937.

Vicente-Serrano, S.M., McVicar, T., Miralles, D., Yang, Y. and Tomas-Burguera, M. (2020) Unravelling the influence of atmospheric evaporative demand on drought under climate dynamics. Wiley Interdisciplinary Reviews-Climate Change, 11, e632. https://doi.org/10.1002/wcc.632.

Wibig, J. (1999) Precipitation in Europe in relation to circulation patterns at the 500 hpa level. International Journal of Climatology, 19, 253-269.

Wibig, J. and Piotrowski, P. (2018) Impact of the air temperature and atmospheric circulation on extreme precipitation in Poland. International Journal of Climatology, 38, 4533-4549.

Wilhite, D.A. (2005) Drought and Water Crises: Science, Technology, and Management Issues. Boca Raton, FL: CRC Press.

Wilhite, D.A. and Pulwarty, R.S. (2017) Drought as hazard: understanding the natural and social context. In: Drought and Water Crises: Integrating Science, Management, and Policy, pp. 3-22. Boca Raton: CRC Press.

Willett, K.M., Dunn, R.J.H., Thorne, P.W., Bell, S., De Podesta, M., Parker, D.E., Jones, P.D. and Williams, C.N. (2014) HadISDH land surface multi-variable humidity and temperature record for climate monitoring. Climate of the Past, 10, 1983-2006.

Wu, Z., Yu, L., Du, Z., Zhang, H., Fan, X. and Lei, T. (2019) Recent changes in the drought of China from 1960 to 2014. International Journal of Climatology, 40, 3281-3296. https://doi.org/ 10.1002/joc.6397.

Yuan, W., Zheng, Y., Piao, S., Ciais, P., Lombardozzi, D., Wang, Y., Ryu, Y., Chen, G., Dong, W., Hu, Z., Jain, A.K., Jiang, C., Kato, E., Li, S., Lienert, S., Liu, S., Nabel, J.E.M.S., Qin, Z., Quine, T., Sitch, S., Smith, W.K., Wang, F., Wu, C., Xiao, Z. and Yang, S. (2019) Increased atmospheric vapor pressure deficit reduces global vegetation growth. Science Advances, 5, eaax1396. https://doi.org/10.1126/sciadv.aax1396.

Zahradníček, P., Brázdil, R., Štěpánek, P. and Řezníčková, L. (2019) Differences in wind speeds according to measured and homogenized series in the Czech Republic, 1961-2015. International Journal of Climatology, 39, 235-250.

Zahradníček, P., Rasol, D., Cindric, K. and Štěpánek, P. (2014) Homogenization of monthly precipitation time series in Croatia. International Journal of Climatology, 34, 3671-3682.

Zscheischler, J., Westra, S., van den Hurk, B.J.J.M., Seneviratne, S. I., Ward, P.J., Pitman, A., AghaKouchak, A., Bresch, D.N., Leonard, M., Wahl, T. and Zhang, X. (2018) Future climate risk from compound events. Nature Climate Change, 8, 469-477.

How to cite this article: Jaagus, J., Aasa, A., Aniskevich, S., Boincean, B., Bojariu, R., Briede, A., Danilovich, I., Castro, F. D., Dumitrescu, A., Labuda, M., Labudová, L., Lõhmus, K., Melnik, V., Mõisja, K., Pongracz, R., Potopová, V., Řezníčková, L., Rimkus, E., Semenova, I., Stonevičius, E., Štěpánek, P., Trnka, M., Vicente-Serrano, S. M., Wibig, J., \& Zahradníček, P. (2022). Long-term changes in drought indices in eastern and central Europe. International Journal of Climatology, 42(1), 225-249. https://doi.org/10.1002/joc.7241 
APPENDIX: List of stations used in this study with their country codes and elevations (m)

\begin{tabular}{|c|c|c|c|}
\hline \multicolumn{2}{|c|}{ No Station } & \multicolumn{2}{|c|}{ Country code Altitude (m) } \\
\hline 1 & Tartu & $\mathrm{EE}$ & 70 \\
\hline 2 & Jõgeva & EE & 70 \\
\hline 3 & Tiirikoja & $\mathrm{EE}$ & 33 \\
\hline 4 & Võru & $\mathrm{EE}$ & 82 \\
\hline 5 & Ristna & $\mathrm{EE}$ & 7 \\
\hline 6 & Kuusiku & $\mathrm{EE}$ & 53 \\
\hline 7 & Kunda & $\mathrm{EE}$ & 3 \\
\hline 8 & Sõrve & $\mathrm{EE}$ & 3 \\
\hline 9 & Türi & $\mathrm{EE}$ & 60 \\
\hline 10 & Valga & $\mathrm{EE}$ & 64 \\
\hline 11 & Viljandi & $\mathrm{EE}$ & 86 \\
\hline 12 & Vilsandi & $\mathrm{EE}$ & 6 \\
\hline 13 & Ainaži & LV & 6 \\
\hline 14 & Alūksne & LV & 197 \\
\hline 15 & Bauska & LV & 30 \\
\hline 16 & Daugavpils & LV & 124 \\
\hline 17 & Jelgava & LV & 5 \\
\hline 18 & Kolka & LV & 4 \\
\hline 19 & Liepāja & LV & 4 \\
\hline 20 & Mērsrags & LV & 4 \\
\hline 21 & Priekuḷi & LV & 122 \\
\hline 22 & Rūjiena & LV & 67 \\
\hline 23 & Saldus & LV & 112 \\
\hline 24 & Ventspils & LV & 2 \\
\hline 25 & Kaunas & LT & 76 \\
\hline 26 & Nida & LT & 2 \\
\hline 27 & Telšiai & LT & 153 \\
\hline 28 & Utena & LT & 105 \\
\hline 92 & Biržai & LT & 60 \\
\hline 30 & Kybartai & LT & 57 \\
\hline 31 & Klaipèda & LT & 6 \\
\hline 32 & Laukuva & LT & 165 \\
\hline 33 & Lazdijai & LT & 133 \\
\hline 34 & Panevėžys & LT & 57 \\
\hline 35 & Raseiniai & LT & 111 \\
\hline 36 & Šiauliai & LT & 106 \\
\hline 37 & Šilutė & LT & 3 \\
\hline 38 & Ukmergė & LT & 72 \\
\hline 39 & Varėna & LT & 109 \\
\hline 40 & Brest & BY & 141 \\
\hline
\end{tabular}

\begin{tabular}{|c|c|c|c|}
\hline \multicolumn{2}{|c|}{ No Station } & \multicolumn{2}{|c|}{ Country code Altitude (m) } \\
\hline 41 & Gorki & BY & 200 \\
\hline 42 & Kostyukovichi & BY & 168 \\
\hline 43 & Mar'ina Gorka & BY & 175 \\
\hline 44 & Minsk & BY & 222 \\
\hline 45 & Pinsk & BY & 140 \\
\hline 46 & Sharkovshchina & BY & 130 \\
\hline 47 & Vasilevichi & BY & 139 \\
\hline 48 & Lida & BY & 152 \\
\hline 49 & Verhnedvinsk & BY & 132 \\
\hline 50 & Vitebsk & BY & 174 \\
\hline 51 & Volkovysk & BY & 180 \\
\hline 52 & Białystok & PL & 139 \\
\hline 53 & Chojnice & PL & 172 \\
\hline 54 & Gorzów & PL & 65 \\
\hline 55 & Hel & PL & 1 \\
\hline 56 & Kasprowy Wierch & PL & 1991 \\
\hline 57 & Kołobrzeg & PL & 3 \\
\hline 58 & Łódź & PL & 187 \\
\hline 59 & Suwałki & PL & 165 \\
\hline 60 & Zakopane & PL & 844 \\
\hline 61 & Wieluń & PL & 195 \\
\hline 62 & Bielsko & PL & 398 \\
\hline 63 & Elbląg & PL & 38 \\
\hline 64 & Jelenia Góra & PL & 342 \\
\hline 65 & Kalisz & PL & 140 \\
\hline 66 & Katowice & PL & 284 \\
\hline 67 & Kielce & PL & 268 \\
\hline 68 & Kłodzko & PL & 316 \\
\hline 69 & Koło & PL & 95 \\
\hline 70 & Koszalin & PL & 33 \\
\hline 71 & Kraków & PL & 222 \\
\hline 72 & Łeba & PL & 2 \\
\hline 73 & Legnica & PL & 121 \\
\hline 74 & Lublin & PL & 171 \\
\hline 75 & Olsztyn & PL & 133 \\
\hline 76 & Opole & PL & 176 \\
\hline 77 & Poznań & PL & 86 \\
\hline 78 & Siedlce & PL & 146 \\
\hline 79 & Słubice & PL & 20 \\
\hline 80 & Szczecin & PL & 1 \\
\hline 81 & Świnoujście & PL & 6 \\
\hline 82 & Zielona Góra & PL & 180 \\
\hline 83 & Tarnow & PL & 209 \\
\hline 84 & Warszawa & PL & 101 \\
\hline
\end{tabular}




\begin{tabular}{|c|c|c|c|c|c|c|}
\hline \multicolumn{2}{|c|}{ No Station } & \multicolumn{2}{|c|}{ Country code Altitude (m) } & \multirow{2}{*}{$\begin{array}{l}\text { No Station } \\
129 \text { Velké Meziříčí }\end{array}$} & \multicolumn{2}{|c|}{ Country code Altitude (m) } \\
\hline & Włodawa & PL & 175 & & $\mathrm{CZ}$ & 452 \\
\hline & Wrocław & PL & 116 & 130 Vráž & $\mathrm{CZ}$ & 433 \\
\hline 87 & Aš & $\mathrm{CZ}$ & 675 & 131 Vsetín & $\mathrm{CZ}$ & 387 \\
\hline 88 & Borkovice & $\mathrm{CZ}$ & 419 & 132 Vyšší Brod & $\mathrm{CZ}$ & 559 \\
\hline 89 & Brno Tuřany & $\mathrm{CZ}$ & 241 & 133 Bratislava-airport & SK & 133 \\
\hline 90 & Broumov & $\mathrm{CZ}$ & 373 & 134 Hurbanovo & SK & 115 \\
\hline & Bystřice pod Hostýnem & $\mathrm{CZ}$ & 314 & 135 Telgart & SK & 900 \\
\hline 92 & České Budějovice & $\mathrm{CZ}$ & 395 & 136 Košice & SK & 230 \\
\hline 93 & Doksy & $\mathrm{CZ}$ & 284 & 137 Kyiv & UA & 166 \\
\hline & Havlíčkův Brod & $\mathrm{CZ}$ & 452 & 138 Lubny & UA & 156 \\
\hline 95 & Hradec Králové & $\mathrm{CZ}$ & 278 & 139 Lviv & UA & 323 \\
\hline 96 & Husinec & $\mathrm{CZ}$ & 483 & 140 Odessa & UA & 42 \\
\hline & Karlovy Vary & $\mathrm{CZ}$ & 377 & 141 Shepetivka & UA & 277 \\
\hline & Klatovy & $\mathrm{CZ}$ & 421 & 142 Uman & UA & 214 \\
\hline & Kostelní Myslová & $\mathrm{CZ}$ & 569 & 143 Uzhhorod & UA & 124 \\
\hline & 0 Kuchařovice & $\mathrm{CZ}$ & 334 & 144 Vinnytsia & UA & 298 \\
\hline & 1 Lednice & $\mathrm{CZ}$ & 177 & 145 Briceni & MO & 242 \\
\hline 102 & 2 Liberec & $\mathrm{CZ}$ & 398 & 146 Chişinău & MO & 173 \\
\hline 103 & 3 Lysá hora & $\mathrm{CZ}$ & 1,322 & 147 Comrat & MO & 133 \\
\hline 104 & 4 Město Albrechtice & $\mathrm{CZ}$ & 498 & 148 Corneşti & MO & 232 \\
\hline 105 & 5 Milešovka & $\mathrm{CZ}$ & 831 & 149 Ştefan Vodă & MO & 173 \\
\hline 106 & 6 Nadějkov & $\mathrm{CZ}$ & 616 & 150 Baia Mare & RO & 224 \\
\hline 107 & 7 Nepomuk & $\mathrm{CZ}$ & 471 & 151 Ocna Şugatag & RO & 508 \\
\hline 108 & 8 Neumětely & $\mathrm{CZ}$ & 322 & 152 Botoşani & RO & 160 \\
\hline 109 & 9 Olomouc & $\mathrm{CZ}$ & 210 & 153 Oradea & RO & 136 \\
\hline 110 & 0 Ondřejov & $\mathrm{CZ}$ & 485 & 154 Iaşi & RO & 103 \\
\hline 111 & 1 Opava & $\mathrm{CZ}$ & 270 & 155 Piatra Neamts & RO & 360 \\
\hline 112 & 2 Plzeň & $\mathrm{CZ}$ & 331 & 156 Roman & RO & 218 \\
\hline 113 & 3 Poděbrady & $\mathrm{CZ}$ & 189 & 157 Cluj-Napoca & RO & 417 \\
\hline 114 & 4 Pohořelice & $\mathrm{CZ}$ & 180 & 158 Alba Iulia & RO & 252 \\
\hline 115 & 5 Praha-Karlov & $\mathrm{CZ}$ & 261 & 159 Blaj & RO & 342 \\
\hline 116 & 6 Praha-Ruzyně & $\mathrm{CZ}$ & 364 & 160 Deva & RO & 230 \\
\hline 117 & 7 Přerov & $\mathrm{CZ}$ & 210 & 161 Timişoara & RO & 86 \\
\hline 118 & 8 Rokytnice v Orlických Horách & $\mathrm{CZ}$ & 577 & 162 Sibiu & RO & 453 \\
\hline 119 & 9 Semčice & $\mathrm{CZ}$ & 234 & 163 Tecuci & RO & 57 \\
\hline 120 & 0 Staré Město & $\mathrm{CZ}$ & 221 & 164 Braşov & RO & 535 \\
\hline 121 & 1 Strakonice & $\mathrm{CZ}$ & 427 & 165 Galați & RO & 71 \\
\hline 122 & 2 Strážnice & $\mathrm{CZ}$ & 176 & 166 Sinaia & RO & 1,510 \\
\hline 123 & 3 Svratouch & $\mathrm{CZ}$ & 734 & 167 Oraviţa & RO & 309 \\
\hline 124 & 4 Tábor & $\mathrm{CZ}$ & 459 & 168 Târgu Jiu & RO & 204 \\
\hline 125 & 5 Teplice & $\mathrm{CZ}$ & 236 & 169 Ploieşti & RO & 172 \\
\hline 126 & 6 Třeboň & $\mathrm{CZ}$ & 428 & 170 Drobeta Turnu Severin & RO & 77 \\
\hline 127 & 7 Ústí nad Orlicí & $\mathrm{CZ}$ & 402 & 171 Bucureşti Filaret & RO & 82 \\
\hline 128 & 8 Valašské Meziř̌čí & $\mathrm{CZ}$ & 334 & 172 Craiova & RO & 192 \\
\hline
\end{tabular}




\begin{tabular}{|lll|}
\hline No Station & \multicolumn{2}{l|}{ Country code Altitude (m) } \\
\hline 173 Calaraşi & RO & 22 \\
\hline 174 Constanţa & RO & 13 \\
\hline 175 Alexandria & RO & 85 \\
176 Turnu Măgurele & RO & 25 \\
\hline 177 Giurgiu & RO & 24 \\
\hline 178 Budapest & HU & 153 \\
\hline 179 Debrecen & HU & 108 \\
\hline 180 Pécs & HU & 203 \\
\hline 181 Szeged & HU & 82 \\
\hline 182 Szombathely & HU & 201 \\
\hline
\end{tabular}

